\title{
5. Sınıf Öğrencilerinin Fen Bilimlerine Yönelik Motivasyonları, Tutumları ve Fen Başarıları Arasındaki İlişki
}

\section{The Relationship Between Fifth-Grade Students' Motivations, Attitudes Towards Science And Science Achievement}

\author{
Hüseyin Cihan BOZDAĞ*
}

\begin{abstract}
Öz: $\mathrm{Bu}$ araştırmada beşinci sınıf öğrencilerinin fen bilimlerine yönelik motivasyon ve tutumlarının birbirleri üzerinde ve fen bilimleri dersi başarısı üzerindeki etkisinin belirlemesi amaçlanmıştır. Araştırma, İzmir şehir merkezindeki bir devlet ortaokulunda öğrenim gören 188 (98'i kız, 90'1 erkek) beşinci sınıf öğrencisi ile yürütülmüştür. Veri toplama aracı olarak Fen öğrenmeye yönelik motivasyon ölçeği (FÖMÖ), Ortaokul öğrencilerine yönelik fen ve teknoloji tutum ölçeği (FBTÖ) ile fen başarı notu için birinci dönem sonu fen bilimleri dersi karne notu kullanılmıştır. Verilerin analizinde betimsel istatistik tekniklerinin yanı sıra, Pearson Momentler Çarpım Korelasyon tekniği ile çoklu doğrusal regresyon analizinden yararlanılmıştır. Elde edilen bulgular, öğrencilerin fen öğrenmeye yönelik motivasyonları ile fen bilimlerine yönelik tutumları arasında pozitif, anlamlı ve orta düzeyde ilişki bulunduğu, öğrencilerin yüksek motivasyon düzeyinde olduğu, tutum düzeylerinin orta seviyede olduğu, fen öğrenmeye yönelik motivasyon ve fen bilimlerine yönelik tutumları ile fen bilimleri dersi başarısı arasında pozitif ve anlamlı bir ilişki olduğunu göstermiştir. Ayrıca, FÖMÖ ve FBTÖ arasındaki ilişkiye yönelik gerçekleştirilen regresyon analizi sonuçlarına göre; FÖMÖ’nün tüm alt boyutlarının öğrencilerin fen bilimlerine yönelik tutumları üzerinde anlamlı bir ilişki sergilediği ile FBTÖ’nün tüm alt boyutlarının öğrencilerin fen öğrenmeye yönelik motivasyonları üzerinde anlamlı bir ilişki sergilediği belirlenmiştir. Sonuç olarak, motivasyon ve tutum gibi duyuşsal faktörlerin öğrencilerin fen bilimleri dersi başarısı üzerinde olumlu etkiler oluşturduğu belirlenmiştir.
\end{abstract}

Anahtar Kelimeler: Başarı, fen, motivasyon, tutum

\begin{abstract}
In this study, it is aimed to investigate the effects of fifth grade students' motivation and attitudes towards science on each other and the science achievement. The study in which the review method was used was conducted with 188 (98 female, 90 male) fifth grade students studying at a secondary school in İzmir city center. Motivation scale for learning science (MSLS), science and technology attitude scale for secondary school students (SCAS), and science grade for end of the first semestr were used as data collection tools. In addition to descriptive statistical techniques, multiple linear regression analysis with pearson moments multiplication correlation technique was used for data analysis. According to the results obtained, it was determined that there is a positive, significant and moderate relationship between students' motivation towards science learning and their attitudes towards science, positive, significant relationship between motivation towards science learning, attitudes towards science and science, students have high motivation level, attitude levels are medium level. According to the results of the regression analysis conducted on the relationship between MSLS and SCAS; It was determined that all sub-dimensions of MSLS showed a significant relationship on students 'attitudes towards science and all sub-dimensions of SCAS showed a significant relationship on students' motivation towards learning science. As a result, it was determined that affective factors such as motivation and attitude had positive effects on students' science achievement.
\end{abstract}

Keywords: Achievement, attitude, motivation, science

\section{Giriş}

Günümüz bilim ve teknoloji çağında, gelişen ve gelişmekte olan tüm toplumların temel eğitim felsefesi araştıran, sorgulayan, problem çözen, yaratıcı, üst düzey düşünme becerilerine haiz geleceğin bireylerini yetiştirmektir. Bununla birlikte küreselleşen dünyada bilginin hızlı

*Fen Bilimleri Öğretmeni, Milli Eğitim Bakanlığı, Gazi Ortaokulu, Buca/İzmir, ORCID: 0000-0001-6735-7096, eposta: chnbzd@gmail.com 
değișimi günümüzde öğrencilerin bilgiyi hatırlamasından ziyade onu ișleme ve kullanma becerilerine sahip olmalarını da zorunlu kılmıștır. Bu durum bireylerin temel bilgi ve becerilerin ötesinde 21. yüzyıl becerileri olarak adlandırılan bir dizi beceriye de sahip olmalarını gerektirmiştir. Çağın şartlarına uyum sağlayan bireylerde bulunması istenilen bu beceriler; yaratıcı ve eleştirel düşünme, bilgi, bilim, iletişim ve medya okuryazarlığı, işbirliği, esneklik ve uyum, problem çözme, iletişim, yaratıcılık ve entelektüel merak becerileri, işbirliği ve sosyal beceriler, öz yönlendirme, hesap verebilirlik ve uyarlanabilirlik ile liderlik becerilerini içermektedir (Partnership For 21st Century Skills, 2013; Şahin, 2009; Uluyol ve Ery1lmaz, 2015).

21. yüzyıl becerileri içerisinde yer alan fen okuryazarlığ kavramı her geçen gün gelişen teknoloji ve eğitim anlayışı ile bir adım daha öne çıkmaktadır. Nitekim, Milli Eğitim Bakanlığınca 2018 yılında yenilenen Fen bilimleri öğretim programı ile bütün bireylerin fen okuryazarı olarak yetişmesi amaçlanmıştır (MEB, 2018). Buna karşın Türk öğrencilerinin fen alanındaki bilgi, beceri ve okuryazarlıklarına ilişkin ulusal ve uluslararası değerlendirme raporları istenilen seviyeye ulaşılamadığını belgelemektedir. Nitekim, Milli Eğitim Bakanlığı'nca hazırlanan ABİDE 2018 (Akademik Becerilerin İzlenmesi ve Değerlendirilmesi) raporuna göre 4. Sınıf öğrencilerinin fen bilimleri alanına ilişkin yeterlilik düzeylerinin; \%11,4 temel alt1, $\% 26,1$ temel, $\% 32,5$ orta, $\% 26,8$ orta üstü ve $\% 3,2$ ileri düzeyde yer aldığı, 8 . sinıf öğrencilerinin fen bilimleri alanına ilişkin yeterlilik düzeylerinin ise $\% 9,4$ temel altı, \%30,4 temel, $\% 46,3$ orta, \%11,4 orta üstü ve $\% 2,5$ ileri düzeyde yer aldığı belirlenmiştir (MEB, 2019a; 2019b). Elde edilen sonuçlar öğrencilerin yaklaşık \%40'ının temel yeterlilik düzeyinde olduğunu, buna karşın üst düzey bilişsel yeteneklere ilişkin becerilerin yer aldığı ileri düzeyde ise yaklaşık \%3'lük bir kısmın yer aldığını göstermektedir. Ayrıca PISA 2015 araştırması ulusal raporunda, öğrencilerin fen okuryazarlığ 1 alanındaki ortalama puanları 425 iken, katılımcı tüm ülkelere ilişkin ortalama puanın 465 olduğu belirtilmiştir. PISA 2015 'de fen okuryazarlığ 1 alanında Türkiye'de 1 . düzey ve altında (alt yeterlik düzeyi) bulunan öğrenci oranı $\% 44,4$, OECD ülkelerinde $\% 23,3$, tüm katılımc1 ülkelerde ise $\% 31,4$ 'tür. 5. düzey ve üstünde (üst yeterlik düzeyi) bulunan öğrenci oranları ise tüm ülkeler için $\% 5,3$, OECD ülkeleri için $\% 7,8$ ve Türkiye için \%0,3'tür (MEB, 2016; OECD, 2018). Elde edilen bu sonuçlar öğrencilerin fen okuryazarlıkları, fen başarıları ve akademik başarıları ile ilişkili bilişsel, duyuşsal ve psikomotor özelliklerle ilgili belirlemeler yapılmasını zorunlu kılmıştır.

Alanyazındaki birçok çalışma bulgusu özellikle duyuşsal özelliklerin öğrencilerin akademik ve/veya belirli bir alan/ders başarısı üzerinde olumlu etkileri olduğunu göstermiştir (Anıl, 2010; Barlia, 1999; Chua ve Karpudewan, 2017; Çakır, Şenler ve Taşkın, 2007; İrven ve Şenler, 2017; MEB, 2016; 2019a; 2019b; OECD, 2018; Ozel, Caglak ve Erdogan, 2013; Potvin ve Hasni, 2014). Duyuşsal beceriler ilgi, tutum, motivasyon, değer, inanç ve öz-yeterlik gibi birçok faktörden oluşmaktadır. Öğrencilerin bilgi ve becerileri üzerinde bu faktörlerin etkilerinin ortaya çıkarılması önemli bir katkı sağlayacaktır. Bu faktörlerden birisi olan motivasyon, öğrencilerin başarılı olmalarında önemli bir faktörolarak kabul edilmektedir (Lee ve Brophy, 1996). Pintrich ve Schunk (2002) tarafindan motivasyon, bireylerin hedefe yönelik eylemleri başlatması ve sürdürmesinde etkili olan süreç olarak tanımlanmıştır. Öğrencilerin akademik faaliyetlerde bulunmaları, belirlenen entelektüel yeterlilik standartlarını karşılamaları, sosyal ilişkiler içerisinde bulunmaları, okul topluluğunun parçası olarak etkinliklerde bulunmaları beklenmektedir. Bu etkinliklerdeki başarılarını anlamanın merkezinde yer alan motivasyon, öğrencilerin okuldaki akademik ve sosyal faaliyetleri için harcadıkları enerji, hangi görevleri yerine getireceklerini belirleyen inançlar, değerler ve hedefler ile bu hedeflere ulaşmadaki kararlılıkları, bir görevin ne zaman tamamlandığına ilişkin belirledikleri standartları ifade eder (Wentzel ve Miele, 2009). Fene yönelik motivasyon ise öğrencilerin fen bilimlerini daha iyi anlamak ve bunu yapmak için aktif stratejiler elde etmeye yönelik fen etkinliklerine katılmaları olarak ifade edilmektedir (Lee ve Brophy, 1996). Motive edilmiş öğrenciler etkinliklere ilgi gösterir, başarılı olmak için çaba harcar ve görevlerine devam ederler. Motive olan öğrenciler genellikle öğrenmek için etkili görev, bilişsel ve öz düzenleme stratejileri kullanırken, öğrencilerin ilgisizliği ve motivasyon eksikliği ise akademik olarak 
başarısızlıklarına zemin hazırlar (Altun, 2006; Pintrich ve Schunk, 2002). Dolayısıyla motivasyonun öğrenme süreçlerinde ihmal edilmemesi ve fen bilimlerine yönelik akademik başarı üzerindeki etkilerinin gözlenmesi önem arz etmektedir. Nitekim, birçok çalışma bulgusu fene yönelik motivasyonun, öğrencilerin akademik başarıları üzerinde olumlu bir etkiye sahip olduğunu göstermiştir (Alkan ve Bayri, 2017; Atay, 2014; Bircan ve Sungur, 2016; Bolat, 2007; Bryan, Glynn ve Kittleson, 2011; Cavas, 2011; Chow ve Yong, 2013; Demir, Öztürk ve Dökme, 2012; Nolen, 2003; Sevinc, Ozmen ve Yigit, 2011; Singh, Granville ve Dika, 2002; Uzun ve Keleş, 2012; Yenice, Saydam ve Telli, 2012). Bunun yanı sıra öğrencilerin fen bilimleri dersi başarılarının, onların motivasyon düzeylerine göre bir farklılık göstermediğine (Ceylan, Sağırekmekçi, Tatar ve Bilgin, 2015) ya da fen öğrenmeye ilişkin motivasyon ile fen başarısı arasında negatif anlamlı ilişki bulunduğuna (Ozel, Caglak ve Erdogan, 2013) ilişkin çalışma bulgularına da rastlamak mümkündür. Diğer bir duyuşsal faktör olan tutum ise kişinin bazı nesne, eylem veya olaylar gibi uyaranlara karşı duygusal boyuttaki genel hissiyatını, olumlu ya da olumsuz görüşlerini ifade eder (Fishbein ve Ajzen, 1975). Tutumlar bireyin gerçekleștirdiği olumlu ya da olumsuz yöndeki değerlendirmelerdir (Hamurcu, 2002). Fen bilimlerine yönelik tutum ise, öğrencilerin fen bilimleri hakkındaki olumlu ve olumsuz düşünceleri olarak tanımlanabilir (Craker, 2006). Tutumlar, karmaşık bir biliş, duygu ve eylem eğilimi sistemini temsil eder ve nihayetinde öğrencilerin fen ve fen ile ilgili konulara yönelik olumlu ve yapıcı tepkiler konusundaki ilgilerini ve eğilimlerini sürdürmelerini etkilemektedir (Bybee ve McCrae, 2011). Öğrencilerin fene yönelik tutumları erken yaşlarda gelişmekte ve 11-12 yaşına gelene kadar hangi konuları sevdiği hakkında kesin tutumları yerleşmektedir. Ancak çevresel faktörlerin etkisiyle birçok öğrenci feni karışık, zor olarak görmektedir. Dolayısıyla öğrencilerin fen bilimlerine yönelik tutumu genel olarak ortaokul ve lise dönemlerinde azalmaktadır. $\mathrm{Bu}$ durum öğrencilerin fen başarılarını etkilemektedir (George, 2000; Hamurcu, 2002). Tutum, öğrencilerin karar ve davranışlarının oluşmasındaki etkisi nedeniyle öğrenmenin gerçekleşmesinde önemli bir rol oynamaktadır (Altınok ve Açıkgöz, 2006). Fen dersinde daha etkin ve kalıcı öğrenmenin sağlanmasında öğrencilerin fen dersine yönelik tutumları önemli bir rol oynamaktadır (Özbaş, 2016). Bu nedenle öğrencilerin fen bilimlerindeki tutumları ile başarıları arasında olumlu bir ilişki olduğu söylenebilir. Alanyazındaki birçok çalışma bulgusu da fen bilimlerine yönelik tutum ile ders başarısı arasında anlamlı bir ilişki olduğuna işaret etmektedir (Anıl, 2010; Gürkan ve Gökçe, 2000; Hough ve Piper, 1982; Ilgaz, 2006; Karaer, 2007; Külçe, 2005; Narmadha ve Chamundeswari, 2013; Papanastasiou ve Zembylas, 2002; Singh, Granville ve Dika, 2002; Sünbül, Afyon, Yağız ve Aslan, 2004; Uyanık, 2017; Yıldırım ve Kansiz, 2017).

Akademik başarının dolaylı ya da doğrudan birçok faktörle ilişkili olduğu ileri sürülmektedir (Sarıer, 2016). Tutum, öz yeterlik, motivasyon, kaygı gibi duyuşsal faktörlerin, başta öğrencilerin derse karşı istek ve ilgilerini olmak üzere birçok faktörü etkileyeceği ve bunun da öğrencilerin performanslarını dolayısıyla akademik başarılarını etkilediği gözlenmektedir (Kan ve Akbaş, 2005). Öğrencilerin belirli bir konu alanında öğrenmelerini etkilemesi ve davranışlarına şekil vermesi nedeniyle özellikle tutum ve motivasyon gibi duyuşsal özeliklerin akademik etkilerinin belirlenmesi yürütülen çalışmaların merkezinde yer almaktadır. Buna karşın ilgili alanyazında duyuşsal faktörler ve bu faktörlerin alt boyutları arasındaki ilişkilerin belirlenmesine yönelik kısıtlı çalışma bulgusuna (Azizoğlu ve Çetin, 2009) rastlanmaktadır. Dolayısıyla öğrencilerin fen başarısı ile tutum ve motivasyonları arasındaki ilişkinin incelenmesi araştırmaya değer bir konu olarak karşımıza çıkmaktadır. Bunun yanı sıra yürütülen çalışmanın güçlü yönlerinden biri de tutum ve motivasyona ilişkin betimsel istatistik değerlerinin karşılaştırılmasından ziyade motivasyon ve tutum duyuşsal faktörlerinin alt boyutlar düzeyinde birbirileri ve fen başarısıyla ilişkisi ve fen başarısı üzerindeki göreli önem sırasının belirlenmeye çalışılmasıdır. Bu yönüyle yordayıcı değişkenlerin birbirleriyle ve fen başarısı ile ilişkisine yönelik bir incelemeye fırsat tanıması yönünden araştırma sonuçlarının alana katkı sağlaması umulmaktadır. Tüm bu anlatımlar ışığında yürütülen çalışmada beşinci sınıf öğrencilerinin fen bilimlerine yönelik tutum ve fen öğrenmeye yönelik motivasyonlarının belirlenmesi ile bu faktörlerin birbirleri ve fen bilimleri dersi başarısı arasındakiilişkinin 
incelenmesi amaçlanmıştır. Bu doğrultuda yürütülen çalışmada aşağıda belirtilen sorulara yanıt aranmıştır.

1- 5. Sınıf öğrencilerinin fen öğrenmeye yönelik motivasyon düzeyleri nedir?

2- Fen öğrenmeye yönelik motivasyon ile alt boyutları arasındaki korelasyon düzeyi nedir?

3- 5. Sınıf öğrencilerinin fen bilimlerine yönelik tutum düzeyleri nedir?

4- Fen bilimlerine yönelik tutum ile alt boyutları arasındaki korelasyon düzeyi nedir?

5- Fen öğrenmeye ilişkin motivasyon, Fen Bilimlerine yönelik tutum ve fen başarısı arasında nasıl bir ilișki vardır?

6- Fen öğrenmeye ilişkin motivasyon ve Fen Bilimlerine yönelik tutumun fen başarısını yordama gücü nedir?

7- Fen başarısı üzerinde fen öğrenmeye ilişkin motivasyon ve Fen Bilimlerine yönelik tutumun önem sirası nedir?

8- Fen öğrenmeye ilişkin motivasyon alt boyutları ve Fen Bilimlerine yönelik tutum alt boyutları birbirleri ile nasıl bir ilişki içindedir?

\section{Yöntem}

\section{Araştırma modeli}

Yürütülen çalışmada beşinci sınıf öğrencilerinin Fen öğrenmeye yönelik motivasyonları ve Fen Bilimlerine yönelik tutumları ile fen bilimleri dersi başarısı arasındaki ilişkinin incelenmesi amaçlanmıştır. $\mathrm{Bu}$ doğrultuda iki ve daha çok sayıdaki değişken arasındaki değişim varlığını veya derecesini belirlemeyi amaçlayan araştırma modeli olan tarama modeli kullanılmıştır (Karasar, 2015). Tekil tarama modeli, değişkenlerin tek tek, tür ya da miktar olarak oluşumlarının belirlenmesini amaçlar. İlişkisel tarama modeli ise, iki ve daha çok sayıdaki değişken arasında birlikte değişim varlığ 1 ve/veya derecesini belirlemeyi amaçlayan araştırma modelleridir (Karasar, 2015). Betimsel olarak, motivasyon, tutum ve fen başarısı analizleri gerçekleştirilmiştir. İlişkisel modele göre ise, motivasyon, tutum ve fen başarısı arasındaki ilişki, fen başarısı üzerinde değişkenlerin göreli önem sırası, motivasyon alt boyutları ve tutum alt boyutları arasındaki ilişki incelenmiştir.

\section{Çalışma grubu}

Araştırmada yer alan gruplar basit seçkisiz örnekleme yöntemi ile seçilmiştir. Basit seçkisiz örnekleme yönteminde evrendeki tüm birimler örneğe seçilmek için eşit ve bağımsız şansa sahiptir (Büyüköztürk ve diğerleri, 2012). Güçlü bir temsil özelliğine sahip örneklem seçiminin geçerli ve en iyi yolu seçkisiz örneklemedir. Seçkisiz örneklemenin dedahil olduğu hiçbir örnekleme evreni tam olarak temsil etme garantsi vermez ancak fakat bu yöntem temsil özelliği bakımından diğerlerinden daha yüksek bir olasılığa sahiptir (Özen ve Gül, 2007).Bu kapsamda araştırma İzmir merkezindeki bir devlet ortaokulunda 2018-2019 eğitim öğretim yılının birinci döneminde beşinci sınıf düzeyinde öğrenim gören toplam 188 öğrenci ile gerçekleştirilmiştir. Öğrencilerin, \%48'i (n=90) erkek ve \%52'si (n=98) kızdır.

\section{Veri toplama araçları}

\section{Fen Öğrenmeye Yönelik Motivasyon Ölçeği}

Dede ve Yaman (2008) tarafından geliştirilerek geçerlik ve güvenirliği sağlanan, Araştırmaya yönelik motivasyon, Performansa yönelik motivasyon, İletişime yönelik motivasyon, İşbirlikli çalışmaya yönelik motivasyon ve Katılıma yönelik motivasyon boyutlarından oluşan "Fen öğrenmeye yönelik motivasyon ölçeği (FÖMÖ)" kullanılmıştır. Ölçek, ikisi olumsuz olmak üzere 23 maddeden oluşan, beşli likert tipi bir ölçme aracıdır.

FÖMÖ tamamında öğrencilerin alabilecekleri puanlar en düşük 23 ve en yüksek 115 puan arasında değişmektedir. FÖMÖ’nün alt boyutlarında ise araştırma yapmaya yönelik 
motivasyon puanları 6 ile 30, performansa yönelik motivasyon puanları 5 ile 25, iletişime yönelik motivasyon puanları 5 ile 25, işbirlikli çalışmaya yönelik motivasyon puanları 4 ile 20 ve katılıma yönelik motivasyon puanları 3 ile 15 puan arasında değişebilmektedir.Ölçekte yer alan alt boyutların madde düzeltilmiş madde toplam korelasyonları 0,24 ile 0,54 arasında değişmektedir. Ölçeğin güvenilirliği Cronbach Alfa iç tutarlık katsayısı ile belirlenmiş ve cronbach alpha güvenilirlik katsayısı 0,672 olarak bulunmuştur.Ölçek araştırmacı tarafından ilgili eğitim öğretim yılının birinci dönemi sonunda bir ders saati içerisinde uygulanmıştır.

\section{Ortaokul Öğrencilerine Yönelik Fen Bilimleri Tutum Ölçeği}

Keçeci ve Zengin (2015) tarafından geçerlik ve güvenilirliği sağlanan "Ortaokul öğrencilerine yönelik fen ve teknoloji tutum ölçeği (FBTÖ)" kullanılmıştır (Ders adı Fen Bilimleri olarak güncellendiğinden, çalışmanın bundan sonraki kısımlarında ölçek Ortaokul öğrencilerine yönelik fen bilimleri tutum ölçeği olarak anılacaktır). Fen bilimlerini sevme ile ilgili tutum, Fen bilimlerine merak ile ilgili tutum ve Fen bilimlerini günlük hayatla ilişkilendirme ile ilgili tutum boyutlarından oluşan beşli likert tipi ölçek on ikisi olumsuz toplam 31 maddeden oluşmaktadır.

FBTÖ bir bütün olarak ele alındığında öğrencilerin alabilceği en düşük puan 31 ve en yüksek puan 155 'dir. FBTÖ'nün alt boyutlarında ise fen bilimlerini sevme ile ilgili tutum puanları 12 ile 60, fen bilimlerine merak ile ilgili tutum puanları 11 ile 55 ve fen bilimlerini günlük hayatla ilişkilendirme tutum puanları 8 ile 40 puan arasında değişebilmektedir. Ölçekte yer alan alt boyutların madde düzeltilmiş madde toplam korelasyonları 0,49 ile 0,70 arasında değişmekte olup; güvenilirlik katsayısı 0,719 olarak belirlenmiştir. Ölçek araştırmacı tarafindan ilgili eğitim öğretim yılının birinci dönemi sonunda bir ders saati içerisinde uygulanmıştır.

Alanyazında farklı değerler belirtilse de genel olarak 0,6-0,8 aralığındaki cronbach alpha değerleri kabul edilebilir olarak değerlendirildiğinden çalışmada kullanılan ölçme araçlarının güvenilir olduğu belirlenmiştir (Hinton, Brownlow, McMurray ve Cozens, 2014; Kılıç, 2016; Mallery ve George, 2003; Özdamar, 1999).

\section{Fen bilimleri dersi başarısı}

Öğrencilerin Fen Bilimleri dersine ilişkin başarılarını belirlemek için uygulamanın yapıldığ 1 eğitim öğretim yılının birinci dönem sonu fen bilimleri dersi karne notu kullanılmıştır. Öğrencilerin fen bilimleri not ortalaması 73.13 , en düşük not 23.56 ve en yüksek not 100 , standart sapmasi ise 15.03 'tür.

\section{Verilerin analizi}

Yürütülen çalışmada beşinci sınıf öğrencilerinin Fen öğrenmeye yönelik motivasyonları, Fen Bilimlerine yönelik tutumları ve fen bilimleri dersi başarısı arasındaki ilişki Pearson Momentler Çarpım Korelasyon tekniği ile hesaplanmıştır. Bu amaçla fen öğrenmeye yönelik motivasyon ve fen bilimlerine yönelik tutumun fen bilimleri dersi başarısı üzerindeki etkisini incelemek için çoklu doğrusal regresyon analizi yapılmıştır. Ancak verilerin çok değişkenli analizinin gerçekleştirilmesi öncesinde i) uç değer, ii) normallik, doğrusallık ile iii) çoklu bağlantı problemi gibi bazı durumların incelenmesi gerekmektedir (Çokluk, Şekercioğlu ve Büyüköztürk, 2014). Uç değerlerin belirlenebilmesi amacıyla öncelikle mahalanobis uzaklık değerleri hesaplanmış ve elde edilen veriler kikare değeri ile karşılaştırılmıştır. Veri setinde gerçekleştirilen inceleme neticesinde dört değerin normallik ve doğrusallık varsayımını güçleştirdiği anlaşılmıştır (Çokluk, Şekercioğlu ve Büyüköztürk, 2014). Dolayısıyla bu dört veriye ilişkin değerler veri setinden çıkarılmış ve regresyon analizi bu doğrultuda gerçekleştirilmiştir.

Bir diğer incelenmesi gereken durum olan normallik varsayımının karşılanabilmesi amaciyla veri setine ilişkin betimsel istatistik verileri değerlendirilmiştir (Tablo 1). Verilerin dağılımlarının, aritmetik ortalama, mod, medyan, çarpıklık ve basıklık gibi istatistikler üzerinden incelenmesi, betimsel yöntemler olarak belirtilmektedir (Abbott, 2011; Kirk, 2008).

FÖMÖ ile FBTÖ'nün her bir boyutundan elde edilen puanların aritmetik ortalama,mod ve medyan değerlerinin birbirine yakın olduğu, çarpıklık ve basıklık değerlerinin -2 ile +2 
aralığında olduğundan normal dağılıma sahip olduğu (George ve Mallery, 2010) görülmektedir. Bunun yanı sıra tüm boyutlarda standart sapma değerlerinin 2'den ve varyasyon katsayılarının 0,50'den düşük değerler alması örneklem dağılımının benzer ve birbiriyle karşılaştırılabilir olduğuna işaret etmektedir (Tektaş, Camgöz ve Metin, 2010).

Tablo 1.

Veri Setine İlișkin Betimsel İstatistik Verileri

\begin{tabular}{lllllllll}
\hline Betimsel Değerler & MB1 & MB2 & MB3 & MB4 & MB5 & TB1 & TB2 & TB3 \\
\hline Ortalama & 4,33 & 4,15 & 4,27 & 4,25 & 4,37 & 4,16 & 3,99 & 4,48 \\
Ortanca & 4,33 & 4,20 & 4,40 & 4,50 & 4,67 & 4,42 & 4,13 & 4,64 \\
Varyans & 0,28 & 0,46 & 0,30 & 0,56 & 0,47 & 0,57 & 0,32 & 0,24 \\
Standart sapma & 0,53 & 0,68 & 0,55 & 0,75 & 0,69 & 0,76 & 0,56 & 0,49 \\
Varyasyon katsayıs1 & 0,12 & 0,16 & 0,13 & 0,18 & 0,16 & 0,18 & 0,14 & 0,11 \\
Değisisim aralığ1 & 2,33 & 2,80 & 2,20 & 3,50 & 3,00 & 3,67 & 2,88 & 2,18 \\
Çarpıklık & $-0,81$ & $-0,55$ & $-0,69$ & $-1,12$ & $-1,24$ & $-1,00$ & $-0,71$ & $-1,23$ \\
Basiklık & 0,28 & $-0,54$ & 0,16 & 1,17 & 1,22 & 0,48 & 0,23 & 1,16 \\
\hline
\end{tabular}

M: Motivasyon, T: Tutum, B: Boyut, Varyasyon katsayısi: Standart sapma/Ortalama

MB1: Araştırma yapmaya yönelik motivasyon, MB2: Performansa yönelik motivasyon, MB3: İletişime yönelik motivasyon, MB4: İşbirlikli çalışmaya yönelik motivasyon, MB5: Katılıma yönelik motivasyon

TB1: Fen bilimlerini sevme ile ilgili tutum, TB2: Fen bilimlerine merak ile ilgili tutum, TB3: Fen bilimlerini günlük hayatla ilişkilendirme ile ilgili tutumu

Regresyon analizinde incelenmesi gereken diğer bir durum ise bağımsız değişkenler arasında çoklu bağlantı probleminin bulunmamasıdır. Alanyazında basit korelasyon matrisinin, bağımsız değişkenler ilave edildiğinde $\mathrm{R}^{2}$ deki değişimin, kısmi korelasyon katsayılarının, varyans artış faktörlerinin (VIF), tolerans değerlerinin (TV) ve durum indeksinin incelenmesi çoklu bağlantı probleminin varlığının saptanmasında tercih edilen unsurlardır. Buna göre eğer VIF değeri 10 'a eşit yada daha büyükse (VIF $\geq 10$ ), TV değerleri 0,10 eşit veya daha küçükse ( TV $\leq 0.10)$ çoklu bağıntı problemi var demektir (Albayrak, 2012; Bahçecitapar ve Aktaş, 2017; Çokluk, Şekercioğlu ve Büyüköztürk, 2014). Veri setinin analizi neticesinde VIF değerleri 1,204-2,363 ve TV değerleri 0,423-0,830 arasında değiştiğinden, değişkenler arasında çoklu bağlantı probleminin bulunmadığ 1 belirlenmiştir. $\mathrm{Bu}$ doğrultuda veri setinde dört verinin dışarıda bırakılmasıyla birlikte 188 veriyle regresyon analizi gerçekleştirilmiştir.

\section{Bulgular}

$\mathrm{Bu}$ bölümde ilk aşamada öğrencilerin fen öğrenmeye yönelik motivasyon düzeyleri ile alt boyutları arasındaki korelasyon, fen bilimlerine yönelik tutum düzeyleri ile alt boyutları arasındaki korelasyon genel olarak incelenmiş, ikinci aşamada ise öğrencilerin fen bilimleri dersi başarısı üzerinde etkisi olduğu düşünülen, FÖMÖ içerisinde yer alan beş ve FBTÖ içinde yer alan üç alt boyut olmak üzere sekiz değişkene yönelik çoklu regresyon analizi gerçekleştirilmiştir.

\section{Sını Ö̆̆rencilerinin Fen Ö̆̆renmeye Yönelik Motivasyon Düzeyleri}

FÖMÖ'nün geneli ve alt boyutlarına ilişkin ortalamalar alınabilecek en düşük ve en yüksek puan birlikte değerlendirilerek düşük, orta ve yüksek düzey olmak üzere üç kategoride değerlendirilmiş̧tir (Tablo 2).

Tablo 2'deki verilere göre; 5. Sınıf öğrencilerinin fen öğrenmeye yönelik motivasyon ortalamas1 $\bar{X}=98,14$ (23.00-53.66: düşük, 53.67-84.32: orta, 84.33-115.00: yüksek), araştırma yapmaya yönelik motivasyon ortalaması $\bar{X}=25,99$ (6.00-14.00: düşük, 14.01-22.00: orta, 22.0130: yüksek), performansa yönelik motivasyon ortalamas $\bar{X}=20,73$ (5.00-11.66: düşük, 11.6718.32: orta ve 18.33-25.00: yüksek), iletişime yönelik motivasyon ortalaması $\bar{X}=21,36$ (5.00- 
11.66: düşük, 11.67-18.32: orta ve 18.33-25.00: yüksek), işbirlikli çalışmaya yönelik motivasyon ortalaması $\bar{X}=16,98$ (4.00-9.33: düşük, 9.34-14.66: orta, 14.67-20.00: yüksek) ve katılıma yönelik motivasyon ortalaması $\bar{X}=13,10$ (3.00-7.00: düşük, 7.01-11.00: orta, 11.0115.00: yüksek) olarak hesaplanmıştır. Elde edilen sonuçlar, 5. sınıf öğrencilerinin fen öğrenmeye, araştırma yapmaya, performansa, iletişime, işbirlikli çalışmaya ve katılıma yönelik motivasyonlarının yüksek düzeyde olduğunu göstermektedir.

Tablo 2.

Fen Öğrenmeye Yönelik Motivasyon İle Alt Boyutlarına İlişsin Betimsel İstatistikler

\begin{tabular}{llll}
\hline \multicolumn{1}{c}{ Değişken } & $\mathrm{N}$ & $\overline{\mathrm{X}}$ & $\mathrm{SS}$ \\
\hline FM: Fen Öğrenmeye Yönelik Motivasyon & 188 & 98,14 & 9,580 \\
M1: Araştırma Yapmaya Yönelik Motivasyon & 188 & 25,99 & 3,189 \\
M2: Performansa yönelik motivasyon & 188 & 20,73 & 3,396 \\
M3: İletişime yönelik motivasyon & 188 & 21,36 & 2,737 \\
M4: İşirlikli çalışmaya yönelik motivasyon & 188 & 16,98 & 2,987 \\
M5: Katılıma yönelik motivasyon & 188 & 13,10 & 2,065 \\
\hline
\end{tabular}

Fen öğrenmeye yönelik motivasyon ile alt boyutları arasındaki korelasyon düzeyi

FÖMÖ iletişime yönelik motivasyon, performansa yönelik motivasyon, araştırma yapmaya yönelik motivasyon, katılıma yönelik motivasyon ve işbirlikli çalışmaya yönelik motivasyon alt boyutlarında oluşmakta olup; FÖMÖ ve alt boyutları arasındaki ilişki pearson korelasyon analizi ile belirlenmiştir (Tablo 3).

Tablo 3.

Fen Öğrenmeye Yönelik Motivasyon İle Alt Boyutları Arasındaki Korelasyon

\begin{tabular}{lcccccc}
\hline Değişkenler & FM & M1 & M2 & M3 & M4 & M5 \\
\hline FM: Fen Öğrenmeye Yönelik Motivasyon & 1 & 0,694 & 0,715 & 0,731 & 0,506 & 0,683 \\
M1: Araştırma Yapmaya Yönelik Motivasyon & & 1 & 0,334 & 0,422 & 0,134 & 0,367 \\
M2: Performansa yönelik motivasyon & & & 1 & 0,443 & 0,077 & 0,455 \\
M3: İletişime yönelik motivasyon & & & & 1 & 0,228 & 0,353 \\
M4: İşbirlikli çalışmaya yönelik motivasyon & & & & & 1 & 0,261 \\
M5: Katılıma yönelik motivasyon & & & & & & 1 \\
\hline
\end{tabular}
$\mathrm{N}=188, \mathrm{p}<0,01$

Tablo 3'te belirtilen pearson korelasyon analizi verilerine göre; fen öğrenmeye yönelik motivasyon ile iletişime yönelik motivasyon $(\mathrm{r}=0,731 ; \mathrm{p}<0,01)$, performansa yönelik motivasyon $(\mathrm{r}=0,715 ; \mathrm{p}<0,01)$ araştırma yapmaya yönelik motivasyon $(\mathrm{r}=0,694 ; \mathrm{p}<0,01)$ ve katılıma yönelik motivasyon $(\mathrm{r}=0,683 ; \mathrm{p}<0,01)$ arasında pozitif ve yüksek düzeyde, işbirlikli çalışmaya yönelik motivasyon $(\mathrm{r}=0,506 ; \mathrm{p}<0,01)$ arasında ise pozitif ve orta düzeyde korelasyon belirlenmiştir. Diğer yandan alt boyutlar arasında ise en yüksek korelasyon katılıma yönelik motivasyon ile performansa yönelik motivasyon arasında $(r=0,455 ; p<0,01)$, en düşük korelasyon ise performansa yönelik motivasyon ile işbirlikli çalışmaya yönelik motivasyon $(\mathrm{r}=0,077 ; \mathrm{p}<0,01)$ arasında tespit edilmiştir.

\section{Sınıf Öğrencilerinin Fen Bilimlerine Yönelik Tutum Düzeyleri}

FBTÖ'nün geneli ve alt boyutlarına ilişkin ortalamalar, alınabilecek en düşük ve en yüksek puan birlikte değerlendirilerek düşük, orta ve yüksek düzey olmak üzere üç kategoride değerlendirilmiştir (Tablo 4). 
Tablo 4.

Fen Bilimlerine Yönelik Tutum İle Alt Boyutlarına İlişkin Betimsel İstatistikler

\begin{tabular}{lccc}
\hline Değişken & $\mathrm{N}$ & $\overline{\mathrm{X}}$ & $\mathrm{SS}$ \\
\hline FT: Fen Bilimlerine Yönelik Tutum & 188 & 133,15 & 16,613 \\
T1: Fen bilimlerini sevme ile ilgili tutum & 188 & 49,95 & 9,077 \\
T2: Fen bilimlerine merak ile ilgili tutum & 188 & 49,25 & 4,492 \\
T3:Fen bilimlerini günlük hayatla ilişkilendirme tutumu & 188 & 31,88 & 5,398 \\
\hline
\end{tabular}

Tablo 4'teki verilere göre; 5. Sınıf öğrencilerinin fen bilimlerine yönelik tutum ortalamas1 $\bar{X}=133,15$ (31.00-72,33: düşük, 72,34-113,67: orta, 113,68-155.00: yüksek), fen bilimlerini sevme ile ilgili tutum ortalamasi $\bar{X}=49,95$ (12,00-28,00: düşük, 28,01-44,01: orta, 44,02-60,00: yüksek), fen bilimlerine merak ile ilgili tutum ortalamas $\bar{X}=49,25(11,00-24,33$ : düşük, 24,34-37,67: orta, 37,68-55,00: yüksek) ve fen bilimlerini günlük hayatla ilişkilendirme tutum ortalamas1 $\bar{X}=31,88$ (8,00-18.66: düşük, 18.67-29,33: orta ve 29,34-40,00: yüksek) olarak hesaplanmıştır. Elde edilen sonuçlar, 5. sınıf öğrencilerinin fen bilimlerine yönelik tutumlarının genel olarak ve alt boyutlar düzeyinde yüksek seviyede olduğunu göstermektedir.

\section{Fen bilimlerine yönelik tutum ile alt boyutları arasındaki korelasyon düzeyi}

Fen öğrenmeye yönelik tutum ile alt boyutları arasındaki ilişki pearson korelasyon analizi ile gerçekleştirilmiştir (Tablo 5).

Tablo 5.

Fen Bilimlerine Yönelik Tutum İle Alt Boyutları Arasındaki Korelasyon

\begin{tabular}{lcccc}
\hline Değişkenler & FT & T1 & T2 & T3 \\
\hline FT: Fen Bilimlerine Yönelik Tutum & 1 & 0,878 & 0,839 & 0,670 \\
T1: Fen bilimlerini sevme ile ilgili tutum & & 1 & 0,558 & 0,342 \\
T2: Fen bilimlerine merak ile ilgili tutum & & & 1 & 0,605 \\
T3: Fen bilimlerini günlük hayatla ilişkilendirme tutumu & & & & 1 \\
\hline \multicolumn{1}{c}{$\mathrm{N}=188, \mathrm{p}<0,01$} & & & &
\end{tabular}

Tablo 5'teki verilere göre; fen bilimlerine yönelik tutum ile fen bilimlerini sevme ile ilgili tutum $(r=0,878 ; p<0,01)$, fen bilimlerine merak ile ilgili tutum $(r=0,839 ; p<0,01)$ ve fen bilimlerini günlük hayatla ilişkilendirme tutumu $(\mathrm{r}=0,670 ; \mathrm{p}<0,01)$ arasında pozitif ve yüksek düzeyde korelasyon belirlenmiştir (Tablo 5). Diğer yandan alt boyutlar arasında ise en yüksek korelasyon fen bilimlerine merak ile ilgili tutum ve fen bilimlerini günlük hayatla ilişkilendirme tutumu arasında $(\mathrm{r}=0,605 ; \mathrm{p}<0,01)$ tespit edilmiştir.

\section{Fen Öğrenmeye İlişkin Motivasyon, Fen Bilimlerine Yönelik Tutum ve Fen Başarısı Arasındaki İlişki}

Öğrencilerin fen bilimleri dersi başarıları ile fen öğrenmeye yönelik motivasyonları ve fen bilimlerine yönelik tutumları arasındaki ilişki pearson korelasyon analizi ile incelenmiştir (Tablo 6).

Tablo 6.

Fen Öğrenmeye İlişkin Motivasyon, Fen Bilimlerine Yönelik Tutum İle Fen Başarısı Arasındaki Korelasyon

\begin{tabular}{lccccc}
\hline \multicolumn{1}{c}{ Değişkenler } & $\overline{\mathrm{X}}$ & Ss & FB & M & T \\
\hline FB: Fen bilimleri dersi başarısı & 73,13 & 15.03 & 1 & & \\
M: Fen öğrenmeye yönelik motivasyon & 4,27 & 0,42 & 0,34 & 1 & \\
T: Fen bilimlerine yönelik tutum & 4,30 & 0,54 & 0,40 & 0,56 & 1 \\
\hline
\end{tabular}

$\mathrm{N}=188, \mathrm{p}<0,01$ 
Tablo 6'da verilen bilgilere gore, fen bilimleri dersi başarısı ile fen bilimlerine yönelik tutum arasında pozitif ve orta düzeyde $(\mathrm{r}=0,400 ; \mathrm{p}<0,01)$, fen bilimleri dersi başarısı ile fen öğrenmeye yönelik motivasyon arasında ise pozitif ve zayıf düzeyde $(\mathrm{r}=0,343 ; \mathrm{p}<0,01)$ korelasyon bulunduğu, fen öğrenmeye yönelik motivasyon ile fen bilimlerine yönelik tutum arasında ise pozitif ve orta düzeyde $(\mathrm{r}=0,560 ; \mathrm{p}<0,01)$ korelasyon bulunduğu tespit edilmiştir.

Diğer yandan FÖMÖ ve FBTÖalt boyutlanı ilefen bilimleri dersi başarısı arasındaki ilişki de pearson korelasyon analizi ile incelenmiiştir (Tablo 7).

Tablo 7.

FÖMÖ Alt Boyutları ve FBTÖ Alt Boyutları İle Fen Bilimleri Dersi Başarısı Arasındaki Korelasyon Değerleri

\begin{tabular}{|c|c|c|c|c|c|c|c|c|c|c|c|c|}
\hline & Değişkenler & $\overline{\mathrm{x}}$ & Ss & D1 & D2 & D3 & D4 & D5 & D6 & D7 & D8 & D9 \\
\hline & D1 Fen başarıs1 & 73,13 & 15.03 & 1 & & & & & & & & \\
\hline \multirow{5}{*}{ 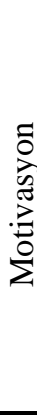 } & $\begin{array}{l}\text { D2 Arasstırma yapmaya } \\
\text { yönelik motivasyon }\end{array}$ & 4,33 & 0,53 & 0,28 & 1 & & & & & & & \\
\hline & $\begin{array}{l}\text { D3 Performansa } \\
\text { yönelik motivasyon }\end{array}$ & 4,15 & 0,68 & 0,16 & 0,33 & 1 & & & & & & \\
\hline & $\begin{array}{l}\text { D4 İletişime yönelik } \\
\text { motivasyon }\end{array}$ & 4,27 & 0,55 & 0,18 & 0,42 & 0,44 & 1 & & & & & \\
\hline & $\begin{array}{l}\text { D5 İşbirlikli çalışmaya } \\
\text { yönelik motivasyon }\end{array}$ & 4,25 & 0,75 & 0,32 & 0,13 & 0,08 & 0,23 & 1 & & & & \\
\hline & $\begin{array}{l}\text { D6 Katılıma yönelik } \\
\text { motivasyon }\end{array}$ & 4,37 & 0,69 & 0,21 & 0,37 & 0,46 & 0,35 & 0,26 & 1 & & & \\
\hline \multirow{3}{*}{ 害 } & $\begin{array}{l}\text { D7 Fen bilimlerini } \\
\text { sevme ile ilgili tutum }\end{array}$ & 4,16 & 0,76 & 0,49 & 0,35 & 0,20 & 0,31 & 0,32 & 0,15 & 1 & & \\
\hline & $\begin{array}{l}\text { D8 Fen bilimlerine } \\
\text { merak ile ilgili tutum }\end{array}$ & 4,48 & 0,49 & 0,27 & 0,58 & 0,39 & 0,42 & 0,17 & 0,28 & 0,56 & 1 & \\
\hline & $\begin{array}{l}\text { D9 Fen bilimlerini } \\
\text { günlük hayatla } \\
\text { ilişkilendirme tutumu }\end{array}$ & 3,99 & 0,56 & 0,10 & 0,54 & 0,34 & 0,27 & 0,08 & 0,20 & 0,34 & 0,61 & 1 \\
\hline
\end{tabular}

Tablo 7'deki verilere gore, FÖMÖ içerisinde yer alan beş ve FBTÖ içinde yer alan üç alt boyut olmak üzere sekiz değişkene yönelik korelasyon değerlerine göre ise fen bilimleri dersi başarısı ile fen bilimlerini sevme ile ilgili tutum arasındaki ilişki en yüksek korelasyon değerine sahiptir $(r=0,49, \mathrm{p}<0,05)$. Bu değeri sırası ile fen bilimleri dersi başarısı ile işbirlikli çalışmaya yönelik $(\mathrm{r}=0,32, \mathrm{p}<0,05)$, fen bilimleri dersi başarısı ile araştırma yapmaya yönelik motivasyon $(\mathrm{r}=0,28, \mathrm{p}<0,05)$, fen bilimleri dersi başarısı ile fen bilimlerine merak ile ilgili tutum $(\mathrm{r}=0,27, \mathrm{p}<0,05)$, fen bilimleri dersi başarısı ile katılıma yönelik motivasyon $(\mathrm{r}=0,21, \mathrm{p}<0,05)$, fen bilimleri dersi başarısı ile iletişime yönelik motivasyon $(r=0,18, p<0,05)$, fen bilimleri dersi başarısı ile performansa yönelik motivasyon $(r=0,16, p<0,05)$, ve fen bilimleri dersi başarısı ile fen bilimlerini günlük hayatla ilişkilendirme ile ilgili tutum $(\mathrm{r}=-0,10, \mathrm{p}<0,05)$ arasındaki ilişkiler takip etmektedir. İlgili değişkenler arasında ise fen bilimlerine merak ile ilgili tutum ve fen bilimlerini günlük hayatla ilişkilendirme ile ilgili tutum arasındaki korelasyonun en yüksek olduğu belirlenmiştir $(\mathrm{r}=0,61, \mathrm{p}<0,05)$.

\section{Fen öğrenmeye yönelik motivasyon ve fen bilimlerine yönelik tutumun fen başarısını yordama gücü}

Öğrencilerin fen bilimleri dersi başarısı üzerinde etkisi olduğu düşünülen, FÖMÖ içerisinde yer alan beş ve FBTÖ içinde yer alan üç alt boyut olmak üzere sekiz değişkene yönelik çoklu regresyon analizi sonucunda, söz konusu değişkenlerin fen bilimleri dersi başarı üzerinde anlamlı bir ilişki $\left(\mathrm{R}=0,552 ; \mathrm{R}^{2}=0.305\right)$ sergiledikleri belirlenmiştir $\left(\mathrm{F}_{8-179}=9,829, \mathrm{p}<0.05\right)$. Belirtme katsayısı $\left(\mathrm{R}^{2}\right)$, doğrusal modelin uyum iyiliğinin en iyi ölçüsüdür. Söz konusu katsayı, 
bağımlı değişkendeki değişimin ne kadarının bağımsız değişken(ler) tarafından açıklandığını ifade eder. Dolayısıyla yürütülen çalışma sonucunda elde edilen veriler belirtilen sekiz değiş̧kenin fen bilimleri dersi puanlarındaki değişimin \%31'ini açıkladığına işaret etmektedir.

Fen başarısı üzerinde fen öğrenmeye yönelik motivasyon ve fen bilimlerine yönelik tutumun önem strast

Fen bilimleri dersi başarısı üzerinde etkisi olduğu düşünülen yordayıcı değişkenlerin önem sırasını belirlemek amacıyla regresyon analizi verileri incelenmiştir (Tablo 8).

Tablo 8.

Fen Bilimlerine Yönelik Tutum, Fen Öğrenmeye Yönelik Motivasyon Ve Fen Bilimleri Ders Başarısına İlişkin Çoklu Regresyon Analizi Sonuçları

\begin{tabular}{lcccc}
\hline Değişkenler & $B$ & Standart Hata & $\beta$ & $\mathrm{t}$ \\
\hline Sabit & 17,497 & 10,589 & & 1,652 \\
Araştırma yapmaya yönelik motivasyon & 5,380 & 2,387 & 0,190 & 2,254 \\
Performansa yönelik motivasyon & 1,357 & 1,715 & 0,061 & 0,791 \\
İletişime yönelik motivasyon & $-1,958$ & 2,091 & $-0,071$ & $-0,936$ \\
İşbirlikli çalışmaya yönelik motivasyon & 3,299 & 1,376 & 0,164 & 2,398 \\
Katılıma yönelik motivasyon & 1,493 & 1,642 & 0,068 & 0,909 \\
Fen bilimlerini sevme ile ilgili tutum & 8,784 & 1,559 & 0,442 & 5,635 \\
Fen bilimlerine merak ile ilgili tutum & $-1,062$ & 2,932 & $-0,035$ & $-0,362$ \\
Fen bilimlerini günlük hayatla & $-4,333$ & 2,219 & $-0,162$ & $-1,952$ \\
ilişsilendirme tutumu & & & & \\
\hline
\end{tabular}

$\mathrm{F}_{8-179}=9,83, \mathrm{p}<0.05 ; \mathrm{R}=0,552 ; \mathrm{R}^{2}=0.305$

Yordayıc1 değişkenlerin fen bilimleri dersi başarısı üzerindeki önem sırası standartlaştırılmış regresyon katsayılarına göre; fen bilimlerini sevme ile ilgili tutum ( $\beta=0.442)$, araştırma yapmaya yönelik motivasyon $(\beta=0.190)$, işbirlikli çalışmaya yönelik motivasyon $(\beta=0.164)$, fen bilimlerini günlük hayatla ilişkilendirme tutumu $(\beta=-0.162)$, iletişime yönelik motivasyon $(\beta=-0.071)$, katılıma yönelik motivasyon $(\beta=0,068)$, performansa yönelik motivasyon $(\beta=0,061)$ ve fen bilimlerine merak ile ilgili tutum $(\beta=-0,035)$ şeklindedir. Bunun yanı sıra her bir değişkene ilişkin B katsayısı değeri fen bilimleri dersi başarısındaki değişime ilişkin sonuçları vermektedir. Örneğin, diğer değişkenler sabit tutulduğunda fen bilimlerini sevme ile ilgili tutumdaki bir birim artış fen bilimleri dersi başarısında 8,784 birimlik artışa, araştırma yapmaya yönelik motivasyondaki bir birim artış fen bilimleri dersi başarısında 5,380 birimlik artışa, fen bilimlerini günlük hayatla ilişkilendirme tutumundaki bir birim azalış ise fen bilimleri dersi başarısında 4,333 birimlik artışa neden olmaktadır.

\section{Fen öğrenmeye yönelik motivasyon alt boyutlart ve fen bilimlerine yönelik tutum alt boyutlart arasındaki ilişki}

FBTÖ'nün alt boyutları ile öğrencilerin fen öğrenmeye yönelik motivasyonları arasındaki ilişki çoklu regresyon analizi ile incelenmiştir (Tablo 9).

Tablo 9.

FBTÖ’nün Alt BoyutlarıIlle Öğrencilerin Fen Öğrenmeye Yönelik Motivasyonlarına İlişkin Çoklu Regresyon Analizi Sonuçları

\begin{tabular}{lcccc}
\hline Değişken & $B$ & Standart Hata & $\beta$ & $\mathrm{t}$ \\
\hline Fen bilimlerini sevme ile ilgili tutum & 0,679 & 0,521 & & 1,302 \\
Araştırma yapmaya yönelik motivasyon & 0,381 & 0,107 & 0,268 & 3,563 \\
Performansa yönelik motivasyon & 0,080 & 0,088 & 0,072 & 0,911 \\
İletişime yönelik motivasyon & 0,191 & 0,109 & 0,139 & 1,758 \\
İşbirlikli çalış̧maya yönelik motivasyon & 0,271 & 0,070 & 0,268 & 3,882 \\
Katıllıma yönelik motivasyon & $-0,107$ & 0,086 & $-0,097$ & $-1,239$ \\
\hline
\end{tabular}




\begin{tabular}{lcccc}
\hline \multicolumn{1}{c}{$\mathrm{R}=0,470 ; \mathrm{R}^{2}=0,221 ; \mathrm{F}_{5-182}=10,297 ; \mathrm{p}<0,05$} & & & \\
\hline Değişken & $B$ & Standart Hata & $\beta$ & $\mathrm{t}$ \\
\hline Fen bilimlerine merak ile ilgili tutum & 1,474 & 0,298 & & 4,952 \\
Araştırma yapmaya yönelik motivasyon & 0,424 & 0,061 & 0,459 & 6,956 \\
Performansa yönelik motivasyon & 0,141 & 0,050 & 0,195 & 2,801 \\
İletişime yönelik motivasyon & 0,120 & 0,062 & 0,134 & 1,931 \\
İşbirlikli çalışmaya yönelik motivasyon & 0,049 & 0,040 & 0,074 & 1,226 \\
Katılıma yönelik motivasyon & $-0,032$ & 0,049 & $-0,044$ & $-0,640$ \\
\hline \multicolumn{1}{c}{$\mathrm{R}=0,630 ; \mathrm{R}^{2}=0,396 ; \mathrm{F}_{5-182}=23,914 ; \mathrm{p}<0,05$} & & & & \\
\hline Değişken & $B$ & Standart Hata & $\beta$ & $\mathrm{t}$ \\
\hline Fen bilimlerini günlük hayatla ilişkilendirme tutumu & 1,226 & 0,360 & & 3,408 \\
Araştırma yapmaya yönelik motivasyon & 0,532 & 0,074 & 0,504 & 7,223 \\
Performansa yönelik motivasyon & 0,173 & 0,061 & 0,210 & 2,858 \\
İletişime yönelik motivasyon & $-0,006$ & 0,075 & $-0,006$ & $-0,086$ \\
İşbirlikli çalışmaya yönelik motivasyon & 0,018 & 0,048 & 0,024 & 0,370 \\
Katılıma yönelik motivasyon & $-0,072$ & 0,059 & $-0,088$ & $-1,203$ \\
\hline \multicolumn{1}{c}{$\mathrm{R}=0,572 ; \mathrm{R}^{2}=0,327 ; \mathrm{F}_{5-182}=17,681 ; \mathrm{p}<0,05$} & & & &
\end{tabular}

Tablo 9'daki verilere göre; "fen bilimlerini sevme ile ilgili tutum" alt boyutu ile öğrencilerin fen öğrenmeye yönelik motivasyonları arasındaki çoklu regresyon analizi neticesinde ilgili değișkenin fen öğrenmeye yönelik motivasyon üzerinde anlamlı bir ilișki sergilediği belirlenmiştir $\left(\mathrm{R}=0,470 ; \mathrm{R}^{2}=0,221 ; \mathrm{F}_{5-182}=10,297 ; \mathrm{p}<0,05\right)$. Fen öğrenmeye yönelik motivasyon, fen bilimlerini sevme ile ilgili tutumun yaklaşık \%22'sini açıklamaktadır. Fen bilimlerini sevme ile ilgili tutum üzerinde değişkenlerin önem sırası standartlaştırılmış regresyon katsayılarına göre; araştırmaya yönelik motivasyon $(\beta=0,268)$, işbirlikli çalışmaya yönelik motivasyon $(\beta=0,268)$, iletişime yönelik motivasyon $(\beta=0,139)$, katılıma yönelik motivasyon $(\beta=-0,097)$ ve performansa yönelik motivasyon $(\beta=0,072)$ şeklindedir. "Fen bilimlerine merak ile ilgili tutum" alt boyutu ile öğrencilerin fen öğrenmeye yönelik motivasyonları arasındaki çoklu regresyon analizi neticesinde ilgili değişkenin fen öğrenmeye yönelik motivasyon üzerinde anlamlı bir ilişki sergilediği belirlenmiştir $\left(R=0,630 ; R^{2}=0,396 ; F_{5}\right.$ $\left.{ }_{182}=23,914 ; \mathrm{p}<0,05\right)$. Fen öğrenmeye yönelik motivasyon, fen bilimlerine merak ile ilgili tutumun yaklaşık \%40'ını açıklamaktadır. Standartlaştırılmış regresyon katsayılarına göre fen bilimlerine merak ile ilgili tutum üzerinde değişkenlerin önem sırası; araştırmaya yönelik motivasyon $(\beta=0,459)$, performansa yönelik motivasyon $(\beta=0,195)$, iletişime yönelik motivasyon $(\beta=0,134)$, işbirlikli çalışmaya yönelik motivasyon $(\beta=0,074)$ ve katılıma yönelik motivasyon $(\beta=-0,044)$ şeklindedir. "Fen bilimlerini günlük hayatla ilişkilendirme tutumu" alt boyutu ile öğrencilerin fen öğrenmeye yönelik motivasyonları arasındaki çoklu regresyon analizi neticesinde ilgili değişkenin fen öğrenmeye yönelik motivasyon üzerinde anlamlı bir ilişki sergilediği belirlenmiştir $\left(R=0,572 ; R^{2}=0,327 ; F_{5-182}=17,681 ; p<0,05\right)$. Fen öğrenmeye yönelik motivasyon, fen bilimlerini günlük hayatla ilişkilendirme tutumunun yaklaşı $\% 33$ 'ünü açıklamaktadır. Standartlaştırılmış regresyon katsayılarına göre fen bilimlerini günlük hayatla ilişkilendirme tutumu üzerinde değişkenlerin önem sırası; araştırmaya yönelik motivasyon $(\beta=0,504)$, performansa yönelik motivasyon $(\beta=0,210)$, katılıma yönelik motivasyon $(\beta=-0,088)$, işbirlikli çalışmaya yönelik motivasyon $(\beta=0,024)$ ve iletişime yönelik motivasyon $(\beta=-0,006)$ şeklindedir.

Bunun yanı sıra FÖMÖ alt boyutları ile öğrencilerin fen bilimlerine yönelik tutumları arasındaki ilişki çoklu regresyon analizi ile incelenmiştir (Tablo 10). 
Tablo 10.

FÖMÖ Alt Boyutlari İle Fen Bilimlerine Yönelik Tutuma Ilişkin Çoklu Regresyon Analizi Sonuçları

\begin{tabular}{|c|c|c|c|c|}
\hline Değişken & $B$ & Standart Hata & $\beta$ & $\mathrm{t}$ \\
\hline Araştırma yapmaya yönelik motivasyon & 1,278 & 0,287 & & 4,446 \\
\hline Fen bilimlerini sevme ile ilgili tutum & 0,029 & 0,049 & 0,041 & 0,590 \\
\hline $\begin{array}{l}\text { Fen bilimlerini günlük hayatla } \\
\text { ilișkilendirme tutumu }\end{array}$ & 0,290 & 0,068 & 0,307 & 4,243 \\
\hline Fen bilimlerine merak ile ilgili tutum & 0,397 & 0,089 & 0,367 & 4,481 \\
\hline \multicolumn{5}{|l|}{$\mathrm{R}=0,625 ; \mathrm{R}^{2}=0,391 ; \mathrm{F}_{3-184}=39,416 ; \mathrm{p}<0,05$} \\
\hline Değişken & $B$ & Standart Hata & $\beta$ & $\mathrm{t}$ \\
\hline Performansa yönelik motivasyon & 1,550 & 0,429 & & 3,616 \\
\hline Fen bilimlerini sevme ile ilgili tutum & $-0,027$ & 0,073 & $-0,030$ & $-0,375$ \\
\hline $\begin{array}{l}\text { Fen bilimlerini günlük hayatla } \\
\text { ilişkilendirme tutumu }\end{array}$ & 0,190 & 0,102 & 0,157 & 1,862 \\
\hline Fen bilimlerine merak ile ilgili tutum & 0,436 & 0,132 & 0,315 & 3,300 \\
\hline \multicolumn{5}{|l|}{$\mathrm{R}=0,413 ; \mathrm{R}^{2}=0,171 ; \mathrm{F}_{3-184}=12,632 ; \mathrm{p}<0,05$} \\
\hline Değişken & $B$ & Standart Hata & $\beta$ & $\mathrm{t}$ \\
\hline İletişime yönelik motivasyon & 2,142 & 0,343 & & 6,242 \\
\hline Fen bilimlerini sevme ile ilgili tutum & 0,082 & 0,058 & 0,113 & 1,411 \\
\hline $\begin{array}{l}\text { Fen bilimlerini günlük hayatla } \\
\text { ilișkilendirme tutumu }\end{array}$ & 0,033 & 0,082 & 0,034 & 0,410 \\
\hline Fen bilimlerine merak ile ilgili tutum & 0,369 & 0,106 & 0,331 & 3,493 \\
\hline \multicolumn{5}{|l|}{$\mathrm{R}=0,427 ; \mathrm{R}^{2}=0,182 ; \mathrm{F}_{3-184}=13,648 ; \mathrm{p}<0,05$} \\
\hline Değişken & $B$ & Standart Hata & $\beta$ & $\mathrm{t}$ \\
\hline İşbirlikli çalışmaya yönelik motiy & 3,028 & 0,491 & & 6,167 \\
\hline Fen bilimlerini sevme ile ilgili tutum & 0,316 & 0,083 & 0,320 & 3,801 \\
\hline $\begin{array}{l}\text { Fen bilimlerini günlük hayatla } \\
\text { ilişkilendirme tutumu }\end{array}$ & $-0,045$ & 0,117 & $-0,033$ & $-0,381$ \\
\hline Fen bilimlerine merak ile ilgili tutum & 0,018 & 0,151 & 0,012 & 0,117 \\
\hline \multicolumn{5}{|l|}{$\mathrm{R}=0,316 ; \mathrm{R}^{2}=0,100 ; \mathrm{F}_{3-184}=6,828 ; \mathrm{p}<0,05$} \\
\hline Değişken & $B$ & Standart Hata & $\beta$ & $\mathrm{t}$ \\
\hline Katılıma yönelik motivasyon & 2,564 & 0,458 & & 5,604 \\
\hline Fen bilimlerini sevme ile ilgili tutum & $-0,005$ & 0,078 & $-0,005$ & $-0,062$ \\
\hline $\begin{array}{l}\text { Fen bilimlerini günlük hayatla } \\
\text { ilişkilendirme tutumu }\end{array}$ & 0,053 & 0,109 & 0,043 & 0,488 \\
\hline Fen bilimlerine merak ile ilgili tutum & 0,360 & 0,141 & 0,257 & 2,551 \\
\hline
\end{tabular}

$\mathrm{R}=0,282 ; \mathrm{R}^{2}=0,080 ; \mathrm{F}_{3-184}=5,299 ; \mathrm{p}<0,05$

Buna göre; FÖMÖ'nün tüm alt boyutlarının öğrencilerin fen bilimlerine yönelik tutumları üzerinde anlamlı bir ilișki sergilediği belirlenmiștir. Fen bilimlerine yönelik tutum araştırma yapmaya yönelik motivasyonun yaklaşık \%39'unu $\left(\mathrm{R}=0,625 ; \mathrm{R}^{2}=0,391 ; \quad \mathrm{F}_{3}\right.$ $\left.{ }_{184}=39,416 ; p<0,05\right)$, iletişime yönelik motivasyonun yaklaşık \% 18 'ini $\left(R=0,427 ; R^{2}=0,182 ; F_{3-}\right.$ $\left.{ }_{184}=13,648 ; \quad \mathrm{p}<0,05\right)$, performansa yönelik motivasyonun yaklaşık \%17'sini $\quad(R=0,413$; $\left.\mathrm{R}^{2}=0,171 ; \quad \mathrm{F}_{3-184}=12,632 ; \mathrm{p}<0,05\right)$, işbirlikli çalışmaya yönelik motivasyonun \%10'unu $\left(\mathrm{R}=0,316 ; \mathrm{R}^{2}=0,100 ; \mathrm{F}_{3-184}=6,828 ; \mathrm{p}<0,05\right)$ ve katılıma yönelik motivasyonun \%8'ini $(\mathrm{R}=0,282$; $\left.\mathrm{R}^{2}=0,080 ; \mathrm{F}_{3-184}=5,299 ; \mathrm{p}<0,05\right)$ açıklamaktadır. Standartlaştırılmış regresyon katsayılarına göre değişkenlerin önem sırası incelendiğinde; araştırmaya yönelik motivasyon, performansa yönelik motivasyon, iletişime yönelik motivasyon ve katılıma yönelik motivasyon üzerinde "fen bilimlerine merak ile ilgili tutumun" en önemli değişken olduğu (sırasıyla $\beta=0,367, \beta=0,315$, $\beta=0,331, \beta=0,257)$, işbirlikli çalışmaya yönelik motivasyon üzerinde ise "fen bilimlerini sevme ile ilgili tutumun en önemli değişken olduğu belirlenmiştir $(\beta=0,320)$. 


\section{Tartışma / Sonuç ve Öneriler}

Yürütülen çalışmada öncelikle, öğrencilerin fen öğrenmeye yönelik motivasyon düzeyleri ile alt boyutları arasındaki korelasyon, fen bilimlerine yönelik tutum düzeyleri ile alt boyutları arasındaki korelasyon genel olarak incelenmiştir. Çalışmadan elde edilen sonuçlar irdelendiğinde 5. Sınıf öğrencilerinin fen öğrenmeye yönelik motivasyon düzeylerine ilişkin betimsel istatistik sonuçları, öğrencilerin fen bilimlerine karşı genel olarak ve alt boyutlar düzeyinde yüksek motivasyon seviyesine sahip olduklarını göstermektedir. Alanyazın incelendiğinde fen öğrenimine yönelik motivasyon düzeylerine ilişkin yapılan birçok çalışmada da öğrencilerin motivasyon düzeylerinin orta ve yüksek düzeyde olduğu belirlenmiştir (Azizoğlu ve Çetin, 2009; Cavas, 2011; Ceylan, Sağırekmekçi, Tatar ve Bilgin, 2015; Chow ve Yong, 2013;Demir, Öztürk ve Dökme, 2012; Singh, Granville ve Dika, 2002). Bu araştırmalara ilaveten Uzun ve Keleş (2012) tarafından öğrencilerin fen öğrenmeye yönelik motivasyon düzeylerinin belirlenmesine yönelik olarak 6., 7. ve 8. sınıflarda öğrenim gören toplam 651 öğrenci ile yürütülen çalışma sonucunda da öğrencilerin FÖMÖ ile alt boyutları baz alındığında motivasyon düzeylerinin oldukça yüksek olduğu sonucuna ulaşılmıştır.

Diğer yandan, fen öğrenmeye yönelik motivasyon ile alt boyutları arasındaki pearson korelasyon verileri, öğrencilerin fen öğrenmeye yönelik motivasyonları ile iletişime yönelik motivasyon, performansa yönelik motivasyon, araştırma yapmaya yönelik motivasyon ve katılıma yönelik motivasyon arasında pozitif ve yüksek düzeyde, işbirlikli çalışmaya yönelik motivasyon arasında ise pozitif ve orta düzeyde korelasyon olduğunu göstermiştir.Benzer şekilde, Uzun ve Keleş (2012) tarafından yürütülen çalışma neticesinde de fen öğrenmeye yönelik motivasyon ve alt boyutları arasında pozitif orta ve yüksek düzeyde korelasyon sonucuna ulaşılmıştır.Demir, Öztürk ve Dökme(2012) 280 öğrenci ile yürüttükleri çalışma neticesinde ortalama motivasyon seviyesinin orta düzeyin üzerinde olduğu ile alt boyutlar incelendiğinde en düşük ortalamanın orta düzey ile işbirlikli çalışmaya yönelik motivasyon olduğu sonucuna ulaşmışlardır.Bu yönüyle öğrencilerin işbirlikli sınıf içi çalışmalarına önem verilmesi gerektiği, bu doğrultuda motivasyonun ve başarının artması yönünde etkili olacağı şeklinde bir değerlendirme yapılması mümkün görünmektedir. Cavas (2011) ise yürüttüğü çalışma neticesinde sınıf düzeyi arttıkça motivasyonun belirgin ölçüde azaldığını belirlemiştir. İlkokul yıllarında öğrenciler kolay ya da zor olsun öğrenme görevlerini yerine getirebilme ve yüksek not alma kabiliyetlerine sahip olduklarına inanmaktadırlar. Buna karşın öğrenciler ortaokul ve liseye geçtiklerinde öğrenme vurgusu katılımdan ziyade performans odağına doğru kaymakta ve motivasyon düzeyi bu değişim çerçevesinde belirgin ölçüde değişime uğramaktadır (Cavas, 2011). Yürütülen araştırmanın çalışma grubunu oluşturan 5. Sınıf öğrencilerinin henüz ilkokuldan ortaokula geçtikleri göz önüne alındığında motivasyon düzeylerinin yüksek olarak belirlenmesi alanyazındaki çalışma bulguları ile örtüşmektedir.

Araştırmadan elde edilen diğer bir sonuç ise 5. sınıf öğrencilerinin fen bilimlerine yönelik tutumlarının genel olarak ve alt boyutlar düzeyinde yüksek seviyede olduğudur. Benzer şekilde Uyanık (2017) 519 öğrenci ile yürüttüğü çalışması neticesinde öğrencilerin fen bilimlerine yönelik orta düzey üstünde tutum seviyesine sahip olduklarına sonucuna ulaşmıştır. Azizoğlu ve Çetin (2009), Ilgaz (2006) ve Külçe (2005)ise ortaokul öğrencileri ile yürüttükleri çalışmalarda öğrencilerin fen dersine yönelik tutum ortalamalarını orta düzeyde belirlemişlerdir.Yapılan araştırmalar öğrencilerin fen derslerine yöneliktutumlarının öğretim kademesi ilerledikçe düşme eğilimi gösterdiğini ortaya koymuştur (Ilgaz, 2006). Nitekim alanyazındaki çalışmaların çoğunluğunda tutum düzeyi orta seviye şeklinde belirlenmiştir. Bu durum göz önüne alındığında yürütülen araştırmada çalışma grubunun 5. Sınıf öğrencileri olması nedeniyle, ilkokuldan ortaokula yeni geçen ve fen bilimleri dersi ile branş bazında ilk kez temas içinde bulunan bu öğrencilerin tutum düzeylerinin yüksek olarak belirlenmesinin bu yönüyle alana katkı sağlayacağı değerlendirilmektedir. Pearson korelasyon analizine göre ise fen bilimlerine yönelik tutum ile fen bilimlerini sevme ile ilgili tutum, fen bilimlerine merak ile ilgili tutum ve fen bilimlerini günlük hayatla ilişkilendirme tutumu arasında pozitif ve yüksek düzeyde korelasyon belirlenmiştir. Öğrencilerin fen bilimleri dersine yönelik tutum düzeylerinin yüksek olması ve alt boyutlar düzeyinde yine yüksek bir korelasyonun bulunduğunun tespit 
edilmesi 5. Sınıf öğrencilerinin fen bilimleri dersini ilgi ile dinledikleri, dersi sevdikleri, öğrenmeye istekli oldukları, meraklarını cezbettiği ve fen bilimleri dersi ile güncel hayatta gerçekleşen olayları daha rahat anladıkları yönünde bir değerlendirilmeye ulaşılmasını mümkün kılmaktadır.

Diğer yandan, öğrencilerin fen bilimleri dersi başarısı, fen öğrenmeye yönelik motivasyonları ve fen bilimlerine yönelik tutumları arasındaki ilişki pearson korelasyon analizi ile incelenmiştir. Buna göre, fen bilimleri dersi başarısı ile fen bilimlerine yönelik tutum arasında pozitif ve orta düzeyde korelasyon bulunduğu tespit edilmiştir. Elde edilen sonuçlar öğrencilerin fen bilimleri ders notu ile tutumları arasında anlamlı bir ilişki olduğu (Karaer, 2007), ilköğretim II. Derece fen bilimleri dersine yönelik tutumların başarı üzerinde pozitif ve anlamlı ilişki içinde olduğu (Anıl, 2010; Narmadha ve Chamundeswari, 2013; Singh, Granville ve Dika, 2002; Sünbül ve diğerleri, 2004; Uyanık, 2017; Yıldırım ve Kansız, 2017), tutum ile ders başarısı arasında doğru bir orantı olduğu (Gürkan ve Gökçe, 2000), başarı durumu yüksek olan öğrencilerin fen bilimleri dersine yönelik tutumlarının da olumlu olduğu (Ilgaz, 2006) sonuçlarını desteklemektedir. Diğer yandan, Bybee ve McCrae (2011) 2006 PISA fen okuryazarlığı üzerinde etkili olan faktörlerden biri olan tutum üzerinde yürüttükleri çalışma neticesinde öğrencilerin tutumlarının konu alanına ilişkin direnç ve ilgisizliklerini etkilediğini belirlemiş̧lerdir. Ceylan, Sağırekmekçi, Tatar ve Bilgin (2015) ise 180 sekizinci sınıf öğrencisi ile yürüttükleri çalışmada fen bilgisine yönelik tutumu yüksek düzeyde olan öğrencilerin fen bilgisi dersi başarılarının da yüksek olduğu buna karşın öğrencilerin fen bilgisi dersi başarılarının, onların motivasyon düzeylerine göre bir farklılık göstermediği sonucuna ulaşmışlardır. Sonuç olarak öğrencilerin fen derslerine yönelik tutumları ile fen başarıları arasında sıkı ilişkiolduğunu ortaya koyan araştırmalar bulunmaktadır (Ilgaz, 2006). Hiç şüphesiz, öğrencilerin fenbilimlerine yönelik tutum düzeyine ilişkin betimsel istatistik sonuçları ile tutum ve fen başarısı arasındaki pearson korelasyon analiz sonuçları bir arada değerlendirildiğinde yüksek tutum düzeyine sahip olan öğrencilerin fen başarısı ile tutumları arasında pozitif ve anlamlı bir ilişkinin belirlenmesi kaçınılmazdır. Elde edilen sonuçlar bu yönüyle alanyazındaki çalışma bulgularını desteklemektedir.

Araştırmadan elde edilen diğer bir sonuç ise fen bilimleri dersi başarısı ile fen öğrenmeye yönelik motivasyon arasında zayıf, pozitif ve anlamlı korelasyon bulunmasıdır. Alanyazındaki birçok çalışmada da fen bilimleri dersi başarısı ile motivasyon arasında (Atay, 2014; Bolat, 2007; Chow ve Yong, 2013; Sevinc, Ozmen ve Yigit, 2011; Yenice, Saydam ve Telli, 2012) pozitif ve anlamlı ilişkiler belirlenmiştir. Benzer şekilde Demir, Öztürk ve Dökme (2012) 280 yedinci sınıf öğrencisi ile yürüttükleri çalışma neticesinde öğrencilerin fen öğrenmeye yönelik motivasyonlarının orta düzeyde olduğu, akademik başarıları ile arasında zayıf ancak pozitif ve anlamlı bir ilişki olduğu sonucuna ulaşmışlardır. Alkan ve Bayri (2017) ise öğrencilerin fene yönelik motivasyonları ile fen başarıları arasındaki ilişkiyi inceleyen 5903 kişilik örneklem hacmine sahip 6 çalışma üzerinde gerçekleştirdikleri meta analiz neticesinde fene yönelik motivasyon ile fen başarısı arasında istatistiksel açıdan anlamlı ve pozitif bir ilişkinin olduğunu belirlemişlerdir. Bircan ve Sungur (2016) ise 861 yedinci sınıf öğrencisi ile yürüttükleri çalışma neticesinde öğrencilerin motivasyonel inançlarının fen başarısını yordamada pozitif ve anlamlı ilişki sergilediği sonucuna varmışlardır. Bilindiği üzere fen öğrenmeye yönelik yüksek motivasyonu olan öğrenciler fen öğrenmede daha başarılıdır (Cavas, 2011).Yürütülen çalışma sonucunda pearson korelasyon ve regresyon analizi sonuçları bir arada değerlendirildiğinde fen başarısı ile motivasyon arasında anlamlı bir ilişki olduğu sonucu alanyazındaki benzer bulgular ile örtüşmektedir.

Araştırmadan elde edilen diğer bir sonuç ise çoklu regresyon analizi sonuçlarına göre yordayıcı değişkenlerin fen bilimleri dersi başarı üzerinde anlamlı bir ilişki sergilemeleridir. FÖMÖ içerisinde yer alan beş ve FBTÖ içinde yer alan üç alt boyut olmak üzere sekiz değişken fen bilimleri dersi puanlarındaki değişimin \%31'ini açıklamaktadır. Fen bilimleri dersi başarısı üzerinde etkisi olduğu düşünülen yordayıcı değişkenlere ilişkin standartlaştırılmış regresyon katsayılarına göre değişkenlerin başarı üzerindeki önem sırası, fen bilimlerini sevme ile ilgili tutum, araştırma yapmaya yönelik motivasyon, işbirlikli çalışmaya yönelik motivasyon, fen 
bilimlerini günlük hayatla ilişkilendirme tutumu, iletişime yönelik motivasyon, katılıma yönelik motivasyon, performansa yönelik motivasyon ve fen bilimlerine merak ile ilgili tutum şeklindedir. Pearson korelasyon analizi sonuçlarına dayalı olarak yürütülen çalışma sonucunda öğrencilerin fen dersi başarısı üzerinde en önemli yordayıcı değişkenlerden birinin tutum olduğu sonucuna ulaşmak mümkündür. Yüksek tutum düzeyine ilişkin elde edilen korelasyon verileri aynı zamanda çoklu regresyon analizi sonuçları ile de örtüşmektedir. Nitekim elde edilen sonuçlar fen başarısı üzerinde göreli önem sırası en yüksek olan yordayıcı değişkenin fen bilimlerini sevme ile ilgili tutum olduğunu göstermektedir. Bunun yanı sıra fen başarısı üzerinde göreli önem sırası yönünden gerçekleştirilen regresyon analizi sonuçları motivasyonun önemli bir değişken olduğuna da işaret etmektedir. Bu bağlamda yürütülen çalışma sonuçlarının her iki değişken ve alt boyutları düzeyinde fen başarısı yönünden ilişkisel bir incelemeye fırsat tanıması yönünden alana katkı sağlayacağı değerlendirilmiştir.

Araştırma sonucunda fen öğrenmeye yönelik motivasyon ile fen bilimlerine yönelik tutum arasında ise pozitif ve orta düzeyde korelasyon bulunduğu tespit edilmiştir. Benzer şekilde Azizoğlu ve Çetin (2009) çalışmalarında motivasyon ile tutum değişkeni arasında istatistiksel olarak anlamlı bir ilişki olduğunu belirlemişlerdir $(\mathrm{r}=0.197, \mathrm{p}<0.001)$. Chua ve Karpudewan (2017) 1003 öğrenci ile yürüttükleri çalışma neticesinde tutum, motivasyon ve fen laboratuar öğrenme ortamı arasında anlamlı bir ilişki olduğunu, motivasyonun fen bilimlerine yönelik tutum geliştirmede önemli bir faktör olduğunu, motivasyon ve algının fen bilimlerine yönelik tutumun önemli birer yordayıcısı olduğunu belirlemişlerdir. Cavas (2011) ise 376 ortaokul öğrencisi ile yürüttüğü çalışma neticesinde öğrencilerin motivasyonel düzeylerinin fene yönelik tutum ve başarı üzerinde önemli etkisi olduğunu, motivasyon düzeyi arttığ ölçüde fene yönelik tutum ve fen başarısının arttığını göstermiştir. Singh, Granville ve Dika (2002) tarafından yürütülen çalışma neticesinde fen bilimlerine yönelik tutum ile motivasyon arasında anlamlı bir ilişki olduğu belirlenmiş, daha fazla motive olan öğrencilerin daha pozitif tutuma sahip oldukları sonucuna ulaşılmıştır. Öğrencilerin başarıya ilişkin motivasyonları yükselerek ders başarıları ve o derse karşı tutumlarının da artmasının sağlanabileceği bilinmektedir (Açıkgöz, 2013). Fen Bilimleri dersine karşı olumlu tutuma sahip olan öğrenci, sonraki öğrenim hayatında da Fen Bilimlerine karşı olumlu tutuma sahip olabilir (Uyanık, 2017). Fen bilimlerine yönelik yerleşen olumsuz tutumlar ise öğrenci motivasyonu ve öğrenmeye yönelik olumsuz faktörlerdir (Barlia, 1999). Öğrencilerin motivasyonları, tutumları ve ilgileri fen eğitiminde önemli unsurlardır. Çünkü bu duygusal unsurlar öğrencilerin fen öğrenimindeki başarısı ile büyük ölçüde ilişkilidir (Cavas, 2011). Dolayısıyla birbirleriyle anlamlı ilişkiler içinde yer alan motivasyon ve tutum fen bilimleri ders alanına ilişkin başarının da artmasına destek olabilir.

Çalışma sonuçları irdelendiğinde FBTÖ’nün alt boyutları ile öğrencilerin fen öğrenmeye yönelik motivasyonları arasındaki çoklu regresyon analizi sonuçlarına göre; "fen bilimlerini sevme ile ilgili tutum", "fen bilimlerine merak ile ilgili tutum" ve "fen bilimlerini günlük hayatla ilişkilendirme tutumu" alt boyutları ile öğrencilerin fen öğrenmeye yönelik motivasyonları arasındaki anlamlı birer ilişki bulunduğu, fen öğrenmeye yönelik motivasyonun, fen bilimlerini sevme ile ilgili tutumun yaklaş1k \%22'sini, fen bilimlerine merak ile ilgili tutumun yaklaşık \%40'1nı, fen bilimlerini günlük hayatla ilişkilendirme tutumunun yaklaşık \%33'ünü açıkladığı görülmektedir. Ayrıca FÖMÖ alt boyutları ile öğrencilerin fen bilimlerine yönelik tutumları arasındaki ilişki de çoklu regresyon analizi ile incelenmiştir. Buna göre; FÖMÖ’nün tüm alt boyutlarının öğrencilerin fen bilimlerine yönelik tutumları üzerinde anlamlı bir ilişki sergilediği, fen bilimlerine yönelik tutumun araştırma yapmaya yönelik motivasyonun yaklaşık \%39'unu, iletişime yönelik motivasyonun yaklaşık \%18'ini, performansa yönelik motivasyonun yaklaşık \%17'sini, işbirlikli çalışmaya yönelik motivasyonun \%10'unu ve katılıma yönelik motivasyonun \%8'ini açıklamaktadır. Alanyazında motivasyon ve tutum değişkenlerinin bir arada ve alt boyutları düzeyinde ayrıntılı bir şekilde incelendiği sınırlı çalışma bulgusuna rastlanmıştır. Dolayısıyla elde edilen sonuçların alanyazındaki sınırlı sayıdaki çalışma bulgularına katkı sağlayacağı değerlendirilmiştir.

Çalışma sonucunda elde edilen sonuçlar birlikte değerlendirildiğinde öğrencilerin fen öğrenmeye yönelik motivasyonları ile fen bilimlerine yönelik tutumları arasında pozitif, anlamlı 
ve orta düzeyde ilişki bulunduğu, öğrencilerin yüksek motivasyon düzeyinde olduğu, tutum düzeylerinin orta seviyede olduğu belirlenmiştir. Hiç şüphesiz, tüm pozitif ve anlamlı ilişkiler sonucunda öğrencilerin fen öğrenmeye yönelik motivasyon ve fen bilimlerine yönelik tutumları ile fen bilimleri dersi başarısı arasında pozitif ve anlamlı bir ilişki olduğu sonucuna ulaşılması kaçınılmazdır. Ancak çalışmanın özgünlüğünü oluşturan motivasyon ve tutum değişkenlerinin alt boyutları nezdinde incelenmesi ve fen başarısı üzerindeki göreli önem sırasının belirlenmesi yöndeki bulgular alana katkı sağlayacak sonuçlar elde edilmesine olanak sağlamıştır. Buna gore fen başarısı üzerinde etkili en önemli yordayıcı değişkenlerin fen bilimlerini sevme ile ilgili tutum, araştırma yapmaya yönelik motivasyon olduğu sonucuna ulaşılmıştır. Bunun yanı sıra çoklu regresyon analizi sonuçları da fen bilimlerine yönelik tutumun araştırma yapmaya yönelik motivasyonun yaklaşık \%39'unu açıkladığını göstermektedir. Dolayısıyla elde edilen sonuçlar tutum ve motivasyonun fen başarısı üzerinde ve birbirleri üzerinde ne denli etkili olduklarını göstermektedir. Diğer yandan özellikle motivasyon ve fen başarısı arasında belirlenen zayıf ilişki uyarınca motivasyonu oluşturan alt boyutların ayrı ayrı incelenmesi gerektiği sonucuna ulaşmak mümkündür. Bu bakımdan öğrencilerin baştaişbirlikli çalışma olmak üzerearaştırma, performans, iletişim ve katılım boyutlarında motivasyonlarını arttırıcı tedbirlerin alınması, öğrencilerin derse yönelik tutumlarına dolayısıyla derse ilişkin başarılarına katkı sağlayacaktır. Tüm bu anlatımların yanı sıra çalışmanın belli sınırlılıkları da bulunmaktadır. Öncelikle çalışmanın en önemli sınırlılığı beşinci sınıf öğrencileri ile yürütülmüş olmasıdır. Çalışma sırasında cinsiyete yönelik bir değerlendirmeye yer verilmemiştir. İlerideki çalışmalarda diğer sınıf düzeylerinde ve cinsiyet faktörünü de içeren bir araştırmaya yer verilebilir. Çalışmanın diğer bir sınırlılığı ise bir ders dönemi notları ile sınırlandırılmış olmasıdır.

Sonuç olarak, doğada ve yakın çevresinde meydana gelen olaylara ilişkin ilgi ve merakı uyanan, üst düzey düşünce becerilerine haiz fen okuryazarı bireyler yetiştirmenin amaçlandığ fen bilimleri öğretim programı çerçevesinde motivasyon ve tutum gibi duyuşsal faktörlerin desteklenmesi öğrencilerin fen bilimleri dersi başarısı üzerinde olumlu etkiler oluşturacaktır. Bu doğrultuda öğretim programlarının uygulayıcıları olan öğretmenlerin öğrencilerin bilişsel özelliklerinin yanında duyuşsal özelliklerine de hitap etmeleri, fen bilimlerine yönelik motivasyon ve tutumlarını destekleyici etkinliklere yer vermeleri ile ögrretim yöntem ve tekniklerine ilişkin bu yönde bir yol izlemelerinin uygun olacağı değerlendirilmektedir.

\section{Kaynaklar}

Abbott, M. L. (2011). Understanding educational statistics using Microsoft Excel and SPSS. United States: John Wiley ve Sons, Inc.

Açıkgöz, K. Ü. (2003). Etkili öğrenme ve ögretme. (4. Baskı). İzmir: Eğitim Dünyası Yayınları.

Albayrak, A. S. (2012). Çoklu doğrusal bağlantı halinde en küçük kareler tekniğinin alternatifi yanlı tahmin teknikleri ve bir uygulama. Uluslararası Yönetim İktisat ve İşletme Dergisi, l(1), 105-126.

Alkan, İ. ve Bayri, N. (2017). Fen öğrenmeye yönelik motivasyon ile fen başarısı arasındaki ilişki üzerine bir meta analiz çalışması. Dicle University Journal of Ziya Gokalp Education Faculty, (32), 865-874

Altınok, H. ve Açıkgöz, K. Ü. (2006). İşbirlikli ve bireysel kavram haritalamanın fen bilgisi dersine yönelik tutum üzerindeki etkileri. Hacettepe Üniversitesi Eğitim Fakültesi Dergisi, 30(30), 21-29.

Altun, S. A. (2009). İlköğretim öğrencilerinin akademik başarısızlıklarına ilişkin veli, öğretmen ve öğrenci görüsslerinin incelenmesi. İlköğretim Online, 8(2), 567-586.

Anıl, D. (2010). Uluslararası öğrenci başarılarını değerlendirme programında (PISA) Türkiye'deki öğrencilerin fen bilimleri başarılarını etkileyen faktörler. Eğitim ve Bilim, 34(152), 87-100.

Atay, A. D. (2014). Ortaokul ögrrencilerinin fen ögrenmeye yönelik motivasyon düzeylerinin ve üstbilişsel farkındalıklarının incelenmesi (Yayımlanmamış yüksek lisans tezi). Adnan Menderes Üniversitesi, Aydın. 
Azizoğlu, N. ve Çetin, G. (2009). 6. ve 7. sınıf öğrencilerinin öğrenme stilleri, fen dersine yönelik tutumları ve motivasyonları arasındaki ilişki. Kastamonu Ĕ̆itim Dergisi 17(1), 171-182.

Barlia, L. (1999). High school student's motivation to engage in conceptual change-learning in science (Yayımlanmamış doktora tezi). The Ohio State University.

Bahçecitapar, M. ve Aktaş, S. (2017). Çoklu doğrusal bağlantı durumunda doğrusal karma modelin kullanımı ve bir uygulama. Sakarya University Journal of Science, 21(6), 13491359.

Bircan, H. ve Sungur, S. (2016). The role of motivation and cognitive engagement in science achievement. Science Education International, 27(4), 509-529.

Bolat, N. K. (2007). İlköğretim 6. ve 7. sinuffen ve teknoloji bilgisi dersi ögrencilerinin öğrenme stillerine göre motivasyon başarı düzeyleri. (Yayımlanmamış yüksek lisans tezi). Fen Bilimleri Enstitüsü. Osmangazi Üniversitesi, Eskişehir.

Bryan, R. R., Glynn, S. M. ve Kittleson, J. M. (2011). Motivation, achievement, and advanced placement intent of high school students learning science. Science education, 95(6), 1049-1065.

Büyüköztürk, Ş., Kılıç Çakmak, E., Akgün, Ö. E., Karadeniz, Ş. ve Demirel, F. (2012). Örnekleme yöntemleri. Erişim adresi. http://w3. balikesir. edu.tr

Bybee, R. ve McCrae, B. (2011). Scientific literacy and student attitudes: Perspectives from PISA 2006 science. International Journal of Science Education, 33(1), 7-26.

Cavas, P. (2011). Factors affecting the motivation of Turkish primary students for science learning. Science Education International, 22(1), 31-42.

Ceylan, E., Sağırekmekçi, H., Tatar, E. ve Bilgin, İ. (2015). Ortaokul öğrencilerinin merak, tutum ve motivasyon düzeylerine göre fen bilgisi dersi başarılarının incelenmesi. Uşak Üniversitesi Sosyal Bilimler Dergisi, 9(1), 39-52.

Chow, S. J. ve Yong, B. C. S. (2013). Secondary school students' motivation and achievement in combined science. Online Submission, 3(4), 213-228.

Chua, K. E. ve Karpudewan, M. (2017). The role of motivation and perceptions about science laboratory environment on lower secondary students' attitude towards science. AsiaPacific Forum on Science Learning and Teaching içinde (Vol. 18, No. 2, pp. 1-16). Hong Kong Institute of Education. 10 Lo Ping Road, Tai Po, New Territories, Hong Kong.

Craker, D. E. (2006). Attitudes toward science of students enrolled in introductory level science courses at UW-La Crosse. UW-L Journal of Undergraduate Research IX, 1-6.

Çakır, N. K., Şenler, B. ve Taşkın, B. G. (2007). İlköğretim II. kademe öğrencilerinin fen bilgisi dersine yönelik tutumlarının belirlenmesi. Türk Eğitim Bilimleri Dergisi, 5(4), 637-655.

Çokluk, Ö., Şekercioğlu, G. ve Büyüköztürk, Ş. (2014). Sosyal bilimler için çok değişkenli istatistik: SPSS ve LISREL uygulamaları (3. Baskı). Ankara: Pegem Akademi.

Dede, Y. ve Yaman, S. (2008). Fen öğrenmeye yönelik motivasyon ölçeği: Geçerlik ve güvenirlik çalışması. Necatibey Eğitim Fakültesi Elektronik Fen ve Matematik Eğitimi Dergisi, 2(1), 19-37.

Demir, R., Öztürk, N. ve Dökme, İ. (2012). İlköğretim 7. sınıf öğrencilerinin fen ve teknoloji dersine yönelik motivasyonlarının bazı değişkenler açısından incelenmesi. Mehmet Akif Ersoy Üniversitesi Ĕ̈itim Fakültesi Dergisi, 1(23), 1-21.

Fishbein, M., ve Ajzen, I. (1975). Belief, Attitude, Intention, and Behavior: An Introduction to Theory and Research.Reading, MA: Addison-Wesley.

George, R. (2000). Measuring change in students' attitudes toward science over time: An application of latent variable growth modeling. Journal of science Education and Technology, 9(3), 213-225.

George, D. ve Mallery, P. (2010). SPSS for Windows step by step. A simple study guide and reference (10. Baskı). Pearson Education India.

Gürkan, T. ve Gökçe, E. (2000). İlköğretim öğrencilerinin fen bilgisi dersine yönelik tutumları. IV. Fen Bilimleri Egitimi Kongresi Bildiri Kitabı, 6-8 Eylül: içinde (ss. 188-192). 
Hamurcu, H. (2002). Fen bilgisi öğretiminde etkili tutumlar. Ĕgitim Araştırmaları Dergisi, 8, 144-152.

Hinton, P. R., Brownlow, C., McMurray, I. ve Cozens, B. (2014). SPSS explained. Routledge.

Hough, L. W. ve Piper, M. K. (1982). The relationship between attitudes toward science and science achievement. Journal of Research in Science Teaching, 19(1), 33-38.

Ilgaz, G. (2006). İlköğretim II. kademe ögrencilerinin fen bilgisi dersine yönelik tutumları ve kullandıkları öğrenme stratejileri (Yayımlanmamış yüksek lisans tezi). Sosyal Bilimler Enstitüsü, Trakya Üniversitesi. Edirne.

İrven, Ö. ve Şenler, B. (2017). İlkokul 4. sınıf öğrencilerinin fen bilimleri dersine yönelik motivasyonel inançları ve öz-düzenleme becerileri. Trakya University Journal of Social Science, $19(2)$.

Kan, A. ve Akbaş, A. (2005). Lise öğrencilerinin kimya dersine yönelik tutum ölçeği geliştirme çalışması. Mersin Üniversitesi Ĕ̈itim Fakültesi Dergisi, 1(2), 227-237.

Karaer, H. (2007). İlköğretim ikinci kademe 8. sınıf öğrencilerinin fen bilgisi dersine yönelik tutumlarının bazı değişkenler açısından incelenmesi. Erzincan Üniversitesi Ĕ̈itim Fakültesi Dergisi, 9(1), 107-120.

Karasar, N. (2015). Bilimsel araştırma yöntemi (28. Baskı).Ankara: Nobel Yayın Dağıtım.

Keçeci, G. ve Zengin, F. K. (2015). Ortaokul öğrencilerine yönelik fen ve teknoloji tutum ölçeği: Geçerlilik ve güvenirlik çalışması. Turkish Journal of Educational Studies, 2(2), 143-168.

Kilıç, S. (2016). Cronbach's alpha reliability coefficient. Journal of Mood Disorders, 6(1), 47.

Kirk, R. E. (2008). Statistics an introduction (Fifth edition). United States: Thomson Higher Education.

Külçe, C. (2005). İlköğretim ikinci kademe ögrencilerinin fen bilgisi dersine yönelik tutumları (Yayımlanmamış yüksek lisans tezi). Fen Bilimleri Enstitüsü, Pamukkale Üniversitesi. Denizli.

Lee, O. ve Brophy, J. (1996). Motivational patterns observed in sixth-grade science classrooms. Journal of Research in Science Teaching: The Official Journal of the National Association for Research in Science Teaching, 33(3), 303-318.

Mallery, P. ve George, D. (2003). SPSS for Windows step by step: a simple guide and reference. Allyn, Bacon, Boston.

Milli Eğitim Bakanlığı (MEB) (2016). PISA 2015 ulusal raporu. Erişim adresi. http://pisa.meb.gov.tr

Milli Eğitim Bakanlı̆̆ (MEB) (2018). Fen bilimleri dersi öğretim programı (İlkokul ve Ortaokul 3, 4, 5, 6, 7 ve 8. Sinıflar). Ankara. Erişim adresi. http://mufredat.meb.gov.tr/

Milli Eğitim Bakanlığı (MEB) (2019a). ABİDE 2018 araştırması 4. Sınıflar özet raporu. Erişim adresi. http://odsgm.meb.gov.tr

Milli Eğitim Bakanlığg (MEB) (2019b). ABİDE 2018 araştırması 8. Sınıflar özet raporu. Erişim adresi. http://odsgm.meb.gov.tr

Narmadha, U. ve Chamundeswari, S. (2013). Attitude towards learning of science and academic achievement in science among students at the secondary level. Journal of Sociological Research, 4(2), 114.

Nolen, S. B. (2003). Learning environment, motivation, and achievement in high school science. Journal of Research in Science Teaching: The Official Journal of the National Association for Research in Science Teaching, 40(4), 347-368.

Organisation for Economic Co-operation and Development (OECD) (2018). PISA 2015 Results in focus. Paris: OECD Publishing. Erişim adresi. https://www.oecd.org/

Ozel, M., Caglak, S. ve Erdogan, M. (2013). Are affective factors a good predictor of science achievement? Examining the role of affective factors based on PISA 2006. Learning and Individual Differences, 24, 73-82.

Özbaş, S. (2016). Lise öğrencilerinin biyoloji dersine yönelik tutumları. Electronic Turkish Studies, 11(9). 659-668.

Özdamar, K. (1999). Paket programlar ile istatistiksel veri analizi 1. Eskişehir: Kaan Kitabevi. 
Özen, Y. ve Gül, A. (2007). Sosyal ve eğitim bilimleri araştirmalarinda evren-örneklem sorunu. Atatürk Üniversitesi Kazım Karabekir Eğitim Fakültesi Dergisi, (15), 394-422.

Partnership For 21st Century Skills, (P21). (2013). Framework For 21st Century Learning. Erişim adresi. https://www.imls.gov/

Papanastasiou, E. C. ve Zembylas, M. (2002). The effect of attitudes on science achievement: A study conducted among high school pupils in Cyprus. International Review of Education, 48(6), 469-484.

Pintrich, P. R. ve Schunk, D. H. (2002). Motivation in education: Theory, research, and applications. Prentice Hall.

Potvin, P. ve Hasni, A. (2014). Interest, motivation and attitude towards science and technology at K-12 levels: a systematic review of 12 years of educational research. Studies in science education, 50(1), 85-129.

Sahin, M. C. (2009). Instructional design principles for 21st century learning skills. ProcediaSocial and Behavioral Sciences, 1(1), 1464-1468.

Sarıer, Y. (2016). Türkiye'de öğrencilerin akademik başarısını etkileyen faktörler: bir metaanaliz çalışması. Hacettepe Üniversitesi Eğitim Fakültesi Dergisi, 31(3), 609-627.

Sevinc, B., Ozmen, H., ve Yigit, N. (2011). Investigation of primary students' motivation levels towards science learning. Science Education International, 22(3), 218-232.

Singh, K., Granville, M. ve Dika, S. (2002). Mathematics and science achievement: Effects of motivation, interest, and academic engagement. The journal of educational research, 95(6), 323-332.

Sünbül, A. M., Afyon, A., Yağız, D. ve Aslan, O. (2004). İlköğretim 2. kademe fen bilgisi derslerinde akademik başarıyı yordamada öğrencilerin öğrenme strateji, stil ve tutumlarının etkisi. XII. Eğitim Bilimleri Kongresi Bildirileri, içinde (ss. 15-18).

Tektaş, Ö. Ö., Camgöz, M. S. ve Metin, İ. (2010). Akademik atıf tarzı: Türkiye ve İngiltere karşı1laştırması. Anatolia: Turizm Araștırmaları Dergisi, 21(1), 17-26.

Uluyol, Ç. ve Eryılmaz, S. (2015). 21. yüzyıl becerileri 1şı̆̆ında fatih projesi değerlendirmesi. Gazi Üniversitesi Gazi Ĕgitim Fakültesi Dergisi, 35(2), 209-229.

Uyanık, G. (2017). İlkokul öğrencilerinin fen bilimleri dersine yönelik tutumları ile akademik başarıları arasındaki ilişki. TÜBAV Bilim Dergisi, 10(1), 86-93.

Uzun, N. ve Keleş, Ö. (2012). İlköğretim öğrencilerinin fen öğrenmeye yönelik motivasyon düzeylerinin değerlendirilmesi/evaluation of primary school students' motivation levels for science learning. Mustafa Kemal Üniversitesi Sosyal Bilimler Enstitüsü Dergisi, 9(20), 313-327.

Yenice, N., Saydam, G. ve Telli, S. (2012). İlköğretim öğrencilerinin fen öğrenmeye yönelik motivasyonlarını etkileyen faktörlerin belirlenmesi. Ahi Evran Üniversitesi Kırşehir Ĕ̈itim Fakültesi Dergisi, 13(2), 231-247.

Yıldırım, H. İ. ve Kansız, F. (2017). Ortaokul öğrencilerinin fen dersine yönelik tutum düzeylerinin bazı değişkenler açısından incelenmesi-2. Turkish Studies-International Periodical for the Languages, Literature and History of Turkish or Turkic, 12, 25.

Wentzel, K. R. ve Miele, D. B. (Eds.). (2009). Handbook of motivation at school. Routledge.

\section{Extended Abstract}

\section{Introduction}

Students' attitudes and motivations towards science play an important role in their performance (An11, 2010; Barlia, 1999; Bryan, Glynn \& Kittleson, 2011; Cavas, 2011; Chow \& Yong, 2013; Chua \& Karpudewan, 2017; Demir, Öztürk \& Dökme, 2012). It has been suggested that academic success is directly and indirectly related to many factors. Affective characteristics can be considered as one of these factors. When considered in this context, it can be thought that affective factors such as attitude, self-efficacy, motivation, anxiety will affect many factors such as students 'desire and interest towards the course and this may affect students' performances and academic achievement (Kan \& Akbaş, 2005). The determination of the academic effects of 
affective characteristics such as attitude and motivation is at the center of the studies carried out since it affects students' learning and shapes their behaviors in a particular subject area. In addition, it is possible to come across the findings of the study to determine the relationships between affective factors (Azizoğlu \& Çetin, 2009). In this context, it is aimed to investigate the effects of fifth grade students' motivation and attitudes towards science on each other and the science achievement. For this purpose, the following questions were sought in the study.

1- What are the motivation levels of 5th grade students towards learning science?

2- What is the correlation between motivation towards learning science and its factors?

3- What are the attitude levels of 5th grade students towards science?

4- What is the correlation between attitudes towards science and its factors?

5- What is the relationship between science achievement and motivation towards science learning and attitude towards science?

6- What is the power of motivation towards science learning and the attitudes towards science to predict science achievement?

7- What is the importance of motivation towards science learning and attitudes towards science on science achievement?

8- How does the motivation towards science learning and the attitude towards science relate to each other?

\section{Method}

The study in which the review method was used was conducted with 188 (98 female, 90 male) fifth grade students studying at a secondary school in İzmir city center. Motivation scale for learning science (MSLS), science and technology attitude scale for secondary school students (SCAS), and science grade for end of the first semestr were used as data collection tools. In addition to descriptive statistical techniques, multiple linear regression analysis with pearson moments multiplication correlation technique was used for data analysis.

\section{Results}

Pearson moments multiplication correlation analysis results show that 5 th grade students have high motivation for learning science, doing research, performing, communicating, collaborating and participating. According to the Pearson correlation analysis between motivation towards learning science and its sub-dimensions; there is a positive and high correlatin between motivation for science learning and communication motivation $(r=0.731 ; p<0.01)$, motivation for science learning and performance motivation $(\mathrm{r}=0.715 ; \mathrm{p}<0.01)$ motivation for science learning and motivation to conduct research $(\mathrm{r}=0.694 ; \mathrm{p}<0.01)$, motivation for science learning and motivation for participation $(\mathrm{r}=0.683 ; \mathrm{p}<0.01)$, positive and moderate correlation between motivation for science learning and motivation for cooperative study $(0.506 ; p<0.01)$. And also, results show that the attitudes of 5th grade students towards science are high in general and sub-dimensions. There is a positive and high correlation between attitude towards science and attitude towards loving science $(\mathrm{r}=0.878 ; \mathrm{p}<0.01)$, attitude towards science and attitude towards curiosity towards science $(\mathrm{r}=0.839 ; \mathrm{p}<0.01)$, and attitude towards science and attitude to associate science with daily life $(r=0.670 ; p<0.01)$. According to pearson correlation analysis results; positive and moderate correlation between the science achievement and attitude towards science $(\mathrm{r}=0,400 ; \mathrm{p}<0,01)$, positive and weak correlation between the science achievement and motivation towards learning science $(\mathrm{r}=0,343 ; 01)$, positive and moderate correlation $(r=0.560 ; \mathrm{p}<0.01)$ between motivation towards science learning and attitude towards science was found, As a result of multiple regression analysis for eight variables, five sub-dimensions in the MSLS and three sub-dimensions in the SCAS, it was found that these variables showed a significant relationship $\left(R=0.552 ; R^{2}=0.305\right)$ on science achievement $\left(\mathrm{F}_{8-179}=9.829, \mathrm{p}<0.05\right)$. The eight variables described account for $31 \%$ of the change in science course scores. The order of significance of the predictive variables on the science achievement is based on standardized regression coefficients; attitude towards loving science $(\beta=0.442)$, motivation to do research $(\beta=0.190)$, motivation for collaborative study ( $\beta$ 
$=0.164)$, attitude towards associating science with daily life $(\beta=-0.162)$, motivation for communication $(\beta=-0.071)$, motivation for participation $(\beta=0.068)$, motivation for performance $(\beta=0.061)$ and attitude towards curiosity for science $(\beta=-0.035)$. According to the results of the regression analysis conducted on the relationship between MSLS and SCAS; It was determined that all sub-dimensions of MSLS showed a significant relationship on students 'attitudes towards science and all sub-dimensions of SCAS showed a significant relationship on students' motivation towards learning science.

\section{Discussion}

When the results obtained from the study are analyzed, descriptive statistics results related to the motivation levels of 5 th grade students towards science learning show that students have high motivation level towards science in general and sub-dimensions. Similarly, in many studies on motivation levels for science learning, students' motivation levels were found to be moderate and high (Azizoğlu \& Çetin, 2009; Cavas, 2011; Ceylan, Sağırekmekçi, Tatar \& Bilgin, 2015; Chow \& Yong, 2013; Demir, Öztürk \& Dökme, 2012; Singh, Granville \& Dika, 2002; Uzun \& Keleş, 2012). Another result obtained from the study is that the attitudes of 5th grade students towards science were high in general and sub-dimensions. The results obtained correspond to the findings of the study in the literature (Azizoğlu \& Çetin, 2009; Ilgaz, 2006; Külçe, 2005). Pearson correlation analysis was used to investigate the relationship between students' achievement in science lesson and their motivation towards science learning and their attitudes towards science. Accordingly, a positive and moderate correlation was found between the achievement of science course and attitude towards science. Another result obtained from the study is that there is a weak, positive and significant correlation between science lesson achievement and motivation for learning science. In many studies in the literature, positive and significant relationships were determined between the success of science courses and motivation (Atay, 2014; Bolat, 2007; Chow \& Yong, 2013; Sevinc, Ozmen \& Yigit, 2011; Yenice, Saydam $\&$ Telli, 2012). Another result obtained from the study is that according to the results of multiple regression analysis, the predictive variables have a significant relationship on science achievement. Eight variable explains $31 \%$ of the change in science course scores, As a result of the study, positive and moderate correlation was found between motivation towards learning science and attitude towards science.

When the results obtained from the study were evaluated together, it was determined that there was a positive, significant and medium level relationship between students' motivation towards science learning and their attitudes towards science, the students had high motivation level and their attitude level was moderate. Undoubtedly, as a result of all positive and meaningful relationships, it is inevitable to conclude that there is a positive and meaningful relationship between students' motivation towards learning science and their attitudes towards science and achievement in science courses. In this respect, taking measures to increase motivation of students in research, performance, communication, participation and cooperative working dimensions will contribute to students' attitudes towards the course and their success in the course. In addition to all these narratives, the study has certain limitations. First of all, the most important limitation of the study was that it was conducted with fifth grade students. No gender-based assessment was included in the study. Further studies may include a study at other grade levels and including gender. Another limitation of the study is that it is limited to one semester grade. As a result, supporting the affective factors such as motivation and attitude within the framework of science curriculum which aims to educate science literate individuals who have high level thinking skills and awakened interest and curiosity about the events taking place in nature and its immediate environment will have positive effects on the success of science course. In this respect, it is considered that teachers, who are the implementers of the curriculums, will address the affective characteristics of the students as well as their cognitive characteristics, include motivational and motivational activities to support their attitudes towards science, and follow a path in this direction regarding the teaching methods and techniques. 